\title{
The Source, Processing and Use of Red Pigment based on Hematite and Cinnabar at Gramalote, an Early Initial Period (1500-1200 cal. B.C.) Maritime Community, North Coast of Peru
}

\author{
Gabriel Prieto $^{1}$, Véronique Wright ${ }^{2}$, Richard L. Burger ${ }^{3}$, Colin A. Cooke ${ }^{4}$, Elvira L. Zeballos- \\ Velasquez $^{5}$, Aldo Watanave ${ }^{6}$, Matthew R. Suchomel ${ }^{7}$ and Leopoldo Suescun ${ }^{8}$
}

\section{Corresponding Author: Gabriel Prieto (oscar.prieto@yale.edu gabrielprietobur@gmail.com)}

\footnotetext{
${ }^{1}$ Ph.D. Proyecto Huanchaco, Universidad Nacional de Trujillo, Peru

${ }^{2}$ IFEA - Instituto Francés de Estudios Andinos, Lima, Perú. UMIFRE 17 MAE / CNRS - USR 3337 América Latina

${ }^{3}$ Department of Anthropology, Yale University, 10 Sachem Street, New Haven, CT, United States 06520-8277.

${ }^{4}$ Department of Earth and Atmospheric Sciences, 1-26 Earth Sciences Building University of Alberta, Edmonton, Alberta, Canada T6G 2E3;

${ }^{5}$ Laboratorio de Cristalografía de Rayos X, Facultad de Ciencias Físicas. Universidad Nacional Mayor de San Marcos, Lima, Peru.

${ }^{6}$ Ministerio de Cultura del Peru.

${ }^{7}$ Advanced Photon Source, Argonne National Laboratory, 9700 S. Cass Ave, Bldg. 433-D003, Argonne, IL 60439, USA

${ }^{8}$ Cryssmat-Lab/Cátedra de Física/DETEMA, Facultad de Química, Universidad de la República, Montevideo 11800, Uruguay
}

(C) 2015. This manuscript version is made available under the Elsevier user license http://www.elsevier.com/open-access/userlicense/1.0/ 


\begin{abstract}
The evidence presented in this paper is a first effort to contextualize aspects related to the sourcing, production and uses of red paint during the second millennium BC in Northern Peru. The site tested was Gramalote, a fishing settlement of the Peruvian North Coast. The results show that the inhabitants of this settlement had access to a local source of hematite but they also used cinnabar that came from a distant region located in the southern highlands. Based on the abundance of lithic and bone tools, shell containers and ceramic seal stamps, the authors of this article study the process behind the production of this painting. Using physicochemical techniques such as Portable X-ray fluorescence (XRF) technology complemented with structural analysis through X-ray diffraction, applying conventional and synchrotron radiation on selected samples, the authors look at issues related to sourcing, production and uses of the red pigment. In addition, isotopic analysis helped to determine the provenience of cinnabar which is also the earliest evidence of human use of this mineral in the Andean region. Temporal and contextual distribution of these artifacts is analyzed to understand the manipulation and uses of the red paint. Finally, this study also gives a glimpse of the symbolic meaning red pigment could have played in the daily life of a second millennium BC maritime community on the Pacific coast of Peru.
\end{abstract}

Keywords: Red pigment; Hematite; Cinnabar; Andean Maritime Communities 


\section{Introduction}

Red pigment has been extensively and broadly used for domestic and ritual purposes in ancient times, both in South America and around the world (Wright 2008; Duarte 2014). Archaeologically, strong evidence supports the fact that red pigments were used by the first settlers who came to South America (Quilter 1989: 82). Some of the earliest contexts of red pigment are in burials of the Paijanense lithic tradition (10,000 BC) on the North Coast of Peru and in burials of the early highland settlements of Lauricocha (Chauchat et al. 2006; Lynch 1980). More recently, the discovery of a camp for mining red pigment at the site of San Ramon 15 on the coast of Chile and associated with the Huentelauquen Complex indicates that the use of hematite and the production of red pigment was not casual but was an organized activity, one that has a long tradition in this part of the continent (Salazar et al. 2011; Salazar et al. 2013).

During later periods (7000-3500 BC) the uses of red pigment are well documented on the coast of Chile, where people of the Chinchorro culture used red paint to cover their dead as well as to decorate fishing gear and ritual paraphernalia (Allison et al. 1984). Red pigment is reported in the village of Paloma in the Central Coast of Peru (Stothert 1985: 621; Quilter 1989: 26-27; 29-30). Red pigments are also present during this period in the southern Andean highlands in the Telarmachay and Pachamachay caves (Julien et al. 1981: 89; Rick 1983: 142).

During the Late Preceramic Period of the Peruvian Prehispanic sequence (3500-2000/1800 BC), coastal settlements such as Asia Unit I in the Southern Central Coast show evidence of processing red paint and leather bags with ground red pigment powder (Engel 1963: 19). A human buried in the sunken circular plaza of the main temple at Aspero, North Central Coast of Peru the dead were painted red (Feldman 1980: 115). During this same period, red pigment is used for the first time to decorate plastered walls in stepped ceremonial platforms. This seems to have been the case on the North Central Coast of Peru at the sites of Caral (close to Aspero), San Juanito (Santa valley, North Central Coast of Peru) as well as at the northern ceremonial center of Ventarron in the Lambayeque valley (Shady 1997: 27; Chapdelaine and Pimentel 2008: 249; Alva 2014: 60, figure 47). Similarly, fishermen of the Late Preceramic at the site of Salinas de Chao, North Coast of Peru used red-painted fishing nets, and brushes of human hair to apply red

paint to other materials. Apparently, the red pigment was stored in and applied from shell containers (Alva 1986: 49). At Alto Salaverry, another Late Preceramic North Coast settlement located in the Moche valley, the excavators found cobbles painted with red and wooden tools 
with traces of use in the production of red mineral (Pozorski and Pozorski 1979a: 375). Finally, in the contemporary fishing community of Huaca Prieta, Junius Bird found shell containers as well as textiles decorated with this color (Bird et al. 1985: 220).

The Initial Period (2000/1800-800 BC) of the Peruvian Prehispanic sequence showed increasing uses of red pigment. It appears in the mural art of the U-shaped centers of the Manchay Culture such as Cardal, Mina Perdida and Garagay on the Central Coast of Peru (Burger and Salazar-Burger 1991; Burger and Salazar-Burger 2009; Ravines and Isbell 1975). Further north, in the ceremonial center of Las Aldas, Rosa Fung found cobbles with red pigment, possibly used to grind the mineral. In the same area, Shelia and Thomas Pozorski found at the ceremonial center of Huaca A-Pampa de Llamas stone mortars, shell containers and ceramic seals associated with the production and use of red pigment (Pozorski and Pozorski 1987: 40-44; Pozorski and Pozorski 1986: 396-397). In the Viru Valley, Thomas Zoubek found that during the middle and especially the late Initial Period, the dead were painted with red pigment at the ceremonial center of Huaca El Gallo and La Gallina (Zoubek 1998: 327). In the Moche valley near the Gramalote fishing settlement, various sites show use of red pigment, for example Huaca Herederos Chica (Caballo Muerto Complex), where Thomas Pozorski found shells used as containers as well as a few cobbles used to grind the red mineral (Pozorski 1976: 110). Finally, in the domestic sector of the highland ceremonial center of Pacopampa in the northern highlands of Peru there is evidence of using red pigment with ceramic stamps (Rosas and Shady 2005: 26).

All this evidence suggests a long term and geographically-extended tradition of coastal and highland early Prehispanic settlements in the Andean region using broadly red pigment from central Chile to northern Peru (Figure 1). In spite of the abundant reports of the presence of these materials, little effort has been made to understand the provenience, processing and uses of the red pigment. Notable exceptions are the recent work of Diego Salazar in the Quebrada San Ramon site where the sources, production and compositional structure of the hematite based red pigment was studied (Salazar et al. 2011; Salazar et al. 2013). In the central Andes, the long term project led by Richard Burger sourcing and tracking cinnabar during the Early Horizon and earlier periods is helping to understand the mobility throughout the central Andes of this element from one mine in the Huancavelica region, although there seems to be a few other sources (Cooke et al. 2013). Similarly, Kevin Vaughn and his research team have been working in the Early Intermediate Period site of Mina Primavera associated with the Nazca society. Vaughn is 
studying the mining process and other cultural practices associated with the exploitation of hematite (Vaughn et al. 2007, 2013a, 2013b). Even though the previous investigations are helpful to clarify the social context, distribution and production of red pigment during the early stages of Andean prehistory, several questions are still to be explored. Where did the red color come from in specific sites? Was it from local or distant sources? Was the red paint made out of hematite or cinnabar? How was the red paint produced? What was the purpose of its use?

The evidence presented in this paper is a first effort to contextualize aspects related to the sourcing, production and uses of red paint during the second millennium BC in Gramalote, a fishing settlement of the Peruvian North Coast. The results show that the inhabitants of this settlement had access to a local source of hematite but they also had access to mercury based mineral (cinnabar) that came from a distant region located in the Southern highlands. Indeed, the cinnabar found at Gramalote is the earliest evidence of this mineral used in the Central Andean region. It also gives us a glimpse of the symbolic meaning red pigment could have played in the daily life of a second millennium BC maritime community on the Pacific coast of Peru.

\section{The Gramalote Site}

Located in the northern sector of the Moche Valley in North Coast of Peru (Central Andean Region), Gramalote is a 2.3 hectare site located on top of a bluff overlooking the ocean, only 250 meters from the shoreline (Figure 2). Ten radiocarbon dates confirm that the site was occupied between 1500 to 1200 cal. BC (Prieto 2014: 8, Table 1) (Table 1). The site has a domestic area located in the southwest sector and a ceremonial building for religious purposes on the northeast sector of the site (Figure 2). During its height, Gramalote housed approximately 300 people living in domestic units which seem to have been organized around a central open space in the southwest (residential) sector of the site (Prieto 2014, 2015) (Figure 2).

Gramalote was once thought to be an extremely specialized fishing settlement of shell gatherers with a narrow range of non-subsistence activities (Pozorski and Pozorski 1979b: 429430). Current investigations show that the Gramalote site was a community with a strong marine-oriented economy with a great diversity of household industries. Those industries took advantage of nearby resources for activities such as basketry (using reeds from the marshlands), carving of seabird and marine mammal bones and drilling of shells (leftovers of daily diet), production of small ceramic objects (specifically ceramic beads and perhaps ceramic miniature 
vessels), and the production of red pigment, which is described in this article. The diet was centered on shark, fish, sea lions, and other marine resources complemented by tubers, legumes, beans and fruits locally grown and obtained by trade with contemporary nearby farming villages (Altamirano et al. 2012; Prieto 2014: 10; Prieto 2015).

Table 1. Radiocarbon measurements obtained from secure contexts, Gramalote

\begin{tabular}{|c|c|c|c|c|c|c|c|c|}
\hline $\begin{array}{l}\text { Sample } \\
\text { Number }\end{array}$ & Material & Provenience & Gramalote Code & $\begin{array}{l}\text { Years } \\
\text { B.P. }\end{array}$ & $\begin{array}{l}\text { 1- } \sigma \text { Calibration } \\
\text { (ShCal 04) } 65.4 \% \\
\end{array}$ & $\begin{array}{l}\text { 2- } \sigma \text { Calibration } \\
(\text { ShCal 04) } 94.6 \%\end{array}$ & $\begin{array}{c}\text { Phase } \\
\text { s }\end{array}$ & $\begin{array}{l}\text { Proposed } \\
\text { Dates }\end{array}$ \\
\hline $\begin{array}{l}\text { BETA- } \\
321936\end{array}$ & $\begin{array}{l}\text { Tillands } \\
\text { ia sp. }\end{array}$ & $\begin{array}{l}\text { Circular Hearth on floor, } \\
\text { West Sector }\end{array}$ & $\begin{array}{l}\text { UII-A6-C2-R4-MF } \\
04\end{array}$ & $\begin{array}{l}3030+/- \\
30 \mathrm{BP}\end{array}$ & $\begin{array}{l}\text { Cal BC } 1264-1129 \\
(68.2 \%)\end{array}$ & $\begin{array}{l}\text { Cal BC 1315-1055 } \\
(94.2 \%) \\
\text { Cal BC } 1369-1358 \\
(1.2 \%)\end{array}$ & \multirow{3}{*}{$\begin{array}{l}\text { PHA } \\
\text { SE } 3\end{array}$} & \multirow{3}{*}{$\begin{array}{c}\text { B.C. } \\
1300- \\
1200\end{array}$} \\
\hline $\begin{array}{l}\text { BETA- } \\
321937\end{array}$ & $\begin{array}{l}\text { Tillands } \\
\text { ia sp. }\end{array}$ & $\begin{array}{l}\text { Circular Hearth on floor, } \\
\text { West Sector }\end{array}$ & $\begin{array}{l}\text { UII-A4-C3-R2-MF } \\
05\end{array}$ & $\begin{array}{l}3140+/- \\
30 \mathrm{BP}\end{array}$ & $\begin{array}{l}\text { Cal BC 1362-1314 } \\
(34.7 \%) \\
\text { Cal BC } 1411-1367 \\
(33.5 \%)\end{array}$ & $\begin{array}{l}\text { Cal BC 1431-1264 } \\
(95 \%) \\
\text { Cal BC 1300-1250 } \\
(4.1 \%)\end{array}$ & & \\
\hline $\begin{array}{l}\text { BETA- } \\
321939 \\
\end{array}$ & $\begin{array}{l}\text { Tillands } \\
\text { ia sp. }\end{array}$ & $\begin{array}{l}\text { Circular Hearth on floor, } \\
\text { East Sector }\end{array}$ & $\begin{array}{l}\text { UIV-A1-3-4-C2- } \\
\text { R5-MF } 12\end{array}$ & $\begin{array}{l}3070+/- \\
30 \mathrm{BP}\end{array}$ & $\begin{array}{l}\text { Cal BC 1317-1212 } \\
(56.3 \%) \\
\text { Cal BC 1372-1344 } \\
(11.9 \%) \\
\end{array}$ & $\begin{array}{l}\text { Cal BC 1390-1153 } \\
(91.5 \%) \\
\text { Cal BC 1146-1129 } \\
(3.9 \%) \\
\end{array}$ & & \\
\hline $\begin{array}{l}\text { BETA- } \\
321938 \\
\end{array}$ & $\begin{array}{l}\text { Tillands } \\
\text { ia sp. }\end{array}$ & $\begin{array}{l}\text { Carbon concentration on } \\
\text { floor, West Sector }\end{array}$ & $\begin{array}{l}\text { UI-A1-3-4-C4-MF } \\
11\end{array}$ & $\begin{array}{l}3180+/- \\
30 \mathrm{BP}\end{array}$ & $\begin{array}{l}\text { Cal BC 1441-1378 } \\
(58.5 \%) \\
\text { Cal BC 1337-1321 } \\
(9.7 \%)\end{array}$ & $\begin{array}{l}\text { Cal BC 1464-1306 } \\
(91.3 \%) \\
\text { Cal BC 1494-1473 } \\
(4.1 \%)\end{array}$ & \multirow{4}{*}{$\begin{array}{l}\text { PHA } \\
\text { SE } 2\end{array}$} & \multirow{4}{*}{$\begin{array}{c}\text { B.C. } \\
1400- \\
1300\end{array}$} \\
\hline $\begin{array}{l}\text { BETA- } \\
321940\end{array}$ & $\begin{array}{l}\text { Tillands } \\
\text { ia sp. }\end{array}$ & $\begin{array}{l}\text { Circular Hearth on floor, } \\
\text { East Sector }\end{array}$ & $\begin{array}{l}\text { UIV-A1-13-C4-R1- } \\
\text { MF } 18\end{array}$ & $\begin{array}{l}3110+/- \\
30 \mathrm{BP}\end{array}$ & $\begin{array}{l}\text { Cal BC 1389-1292 } \\
(63.9 \%) \\
\text { Cal BC } 1279-1271 \\
(4.3 \%)\end{array}$ & $\begin{array}{l}\text { Cal BC 1416-1251 } \\
(90.1 \%) \\
\text { Cal BC } 1243-1213 \\
(5.3 \%)\end{array}$ & & \\
\hline $\begin{array}{l}\text { BETA- } \\
321941 \\
\end{array}$ & $\begin{array}{l}\text { Tillands } \\
\text { ia sp. }\end{array}$ & $\begin{array}{l}\text { Circular Hearth on floor, } \\
\text { West Sector }\end{array}$ & $\begin{array}{l}\text { UII-A1-2-4-C6- } \\
\text { R13-MF 35 }\end{array}$ & $\begin{array}{l}3040+/- \\
30 \mathrm{BP}\end{array}$ & $\begin{array}{l}\text { Cal BC 1272-1189 } \\
(44.9 \%) \\
\text { Cal BC } 1293-1278 \\
(6 \%)\end{array}$ & $\begin{array}{l}\text { Cal BC 1321-1112 } \\
(88.1 \%) \\
\text { Cal BC 1377-1337 } \\
(5.3 \%)\end{array}$ & & \\
\hline $\begin{array}{l}\text { BETA- } \\
321942 \\
\end{array}$ & $\begin{array}{l}\text { Tillands } \\
\text { ia sp. }\end{array}$ & $\begin{array}{l}\text { Circular Hearth on floor, } \\
\text { West Sector }\end{array}$ & $\begin{array}{l}\text { UII-A5-6-C6-MF } \\
36\end{array}$ & $\begin{array}{l}3140+/- \\
30 \mathrm{BP}\end{array}$ & $\begin{array}{l}\text { Cal BC 1362-1314 } \\
(34.7 \%) \\
\text { Cal BC } 1411-1367 \\
(33.5 \%)\end{array}$ & $\begin{array}{l}\text { Cal BC 1431-1264 } \\
(95.4 \%)\end{array}$ & & \\
\hline $\begin{array}{l}\text { BETA- } \\
321943 \\
\end{array}$ & $\begin{array}{l}\text { Tillands } \\
\text { ia sp. }\end{array}$ & $\begin{array}{l}\text { Circular Hearth on floor, } \\
\text { West Sector }\end{array}$ & $\begin{array}{l}\text { UI-A1-2-4-C7-R12- } \\
\text { MF } 38\end{array}$ & $\begin{array}{l}3200+/- \\
30 \mathrm{BP} \\
\end{array}$ & $\begin{array}{l}\text { Cal BC 1456-1390 } \\
(63.3 \%) \\
\text { Cal BC 1490-1481 } \\
(4.9 \%) \\
\end{array}$ & $\begin{array}{l}\text { Cal BC 1500-1370 } \\
(87.7 \%) \\
\text { Cal BC 1346-1316 } \\
(7.7 \%) \\
\end{array}$ & \multirow{3}{*}{$\begin{array}{l}\text { PHA } \\
\text { SE } 1\end{array}$} & \multirow{2}{*}{$\begin{array}{c}\text { B.C. } \\
1500- \\
1400\end{array}$} \\
\hline $\begin{array}{l}\text { BETA- } \\
321945\end{array}$ & $\begin{array}{l}\text { Tillands } \\
\text { ia sp. }\end{array}$ & $\begin{array}{l}\text { Circular Hearth on floor, } \\
\text { West Sector }\end{array}$ & $\begin{array}{l}\text { UII-A5-6-C7- } \\
\text { AMB1-R3-MF } 41\end{array}$ & $\begin{array}{l}3130+/- \\
30 \mathrm{BP}\end{array}$ & $\begin{array}{l}\text { Cal BC 1404-1311 } \\
(68.2 \%)\end{array}$ & $\begin{array}{l}\text { Cal BC } 1429-1260 \\
(95.4 \%)\end{array}$ & & \\
\hline $\begin{array}{l}\text { BETA- } \\
321946\end{array}$ & $\begin{array}{l}\text { Tillands } \\
\text { ia sp. }\end{array}$ & $\begin{array}{l}\text { Pit filled with ash and } \\
\text { carbon }\end{array}$ & $\begin{array}{l}\text { UII-A5-6-C7-R20- } \\
\text { MF } 45\end{array}$ & $\begin{array}{l}3170+/- \\
30 \mathrm{BP}\end{array}$ & $\begin{array}{l}\text { Cal BC } 1433-1375 \\
(54 \%) \\
\text { Cal BC } 1339-1320 \\
(14.2 \%)\end{array}$ & $\begin{array}{l}\text { Cal BC 1457-1294 } \\
(93.9 \%) \\
\text { Cal BC 1491-1479 } \\
(1.5 \%)\end{array}$ & & \\
\hline
\end{tabular}

\section{Artifacts with Red Pigment at Gramalote}

Although we have already describe in the first section of this article that several early sites along the coast of the Central Andean region have shown the presence of cultural materials associated with the use of red pigment, the large quantity of artifacts associated with this product at Gramalote is astonishing (Table 2). 
Table 2. Materials associated with red paint found in Gramalote

\begin{tabular}{|l|r|r|r|r|}
\hline Category & UNIT I & UNIT II & UNIT IV & TOTAL \\
\hline LITHICS & 27 & 127 & 195 & 349 \\
\hline SHELLS & 17 & 48 & 46 & 111 \\
\hline CERAMIC BEADS & 3 & 24 & 26 & 53 \\
\hline MINERAL & 0 & 8 & 0 & 8 \\
\hline BONE OBJECTS & 0 & 3 & 1 & 4 \\
\hline ANHTRACITE & 4 & 15 & 14 & 33 \\
\hline TEXTILES & 9 & 16 & 43 & 68 \\
\hline CERAMIC STAMPS & 0 & 2 & 1 & 3 \\
\hline CERAMIC MINIATURES & 0 & 2 & 0 & 2 \\
\hline CERAMIC FIGURINES & 1 & 1 & 0 & 2 \\
\hline HUMAN BODIES & 0 & 1 & 1 & 2 \\
\hline TOTAL & 61 & 247 & 327 & 635 \\
\hline
\end{tabular}

In total, the discovery of 635 artifacts at Gramalote indicates that red pigment was widely used there. The artifacts were found both in the residential and ceremonial sector of the site in direct association with floors, votive offerings, graves, and especially in the fills that covered the occupational surfaces of the site. The artifact included small chunks of red mineral, grinding stones or cobbles with red pigment usually on one surface, flat stones that may have served for grinding the pigment, bone tools for processing and perhaps applying the pigment, shells of clams and mussels which appear to have been used as pigment containers, anthracite plates and shallow bowls for the same purpose, cotton swabs for applying the pigment and ceramic stamps with fancy designs possibly used to print red patterns on different surfaces (Figures 3 and 4). In addition several pieces of cotton fabric and cordage as well as carved bones and ceramic beads were decorated with red pigment (Figure 5). From the 50 human bodies excavated at Gramalote the dead were rarely painted red $(n=2)$, usually on the face area (Figure 6). Interestingly, four individuals were buried containing red paint as grave offerings: three had a gourd container with the pigment and a single case was buried with a "set" for processing red pigment: a shell container, a bone spatula and a ceramic seal stamp (Figure 7). This pattern notably contrast with the contemporary Initial Period occupation around Huaca Prieta, where Junius Bird found several bodies with red paint (Bird et al. 1985)

\section{Method}


Using physicochemical techniques to study these remains helps to understand issues concerning the composition of the red pigment. For example, it is important to define the composition of the red paint present in the two different sectors of the site (residential and ceremonial) to determine whether they are similar or different. These data are relevant to infer the role of this pigment at Gramalote. Similarly, the presence of tools related to the preparation of red pigment is crucial to understanding the production process. The analytical study of these artifacts therefore helps to determine the chaîne operatoire. Finally, understanding the geological provenience (sourcing) of the minerals used to produce the red pigment is important if we are to understand the selection process and the circulation of these materials in the region. It will also help determine if the Gramalote population had access to distant sources, which would in turn tell us about social interaction during the early Initial Period on the North Coast of Peru.

\subsection{Sampling}

Red pigment is present in the two sectors of the site (domestic and ceremonial) from the earliest (Phase 1 and 2) through the later occupations (Phase 3). Many materials, such as stone tools, ceramics, shells, textiles and bones, show evidence of being part of processing or using the red paint. Therefore, we have selected 46 samples taken from 16 stone tools, 9 ceramic vessels, 14 shell containers, 3 pieces of textiles and 4 carved bones. The artifacts chosen comprise 28 from the domestic sector and 18 from the ceremonial sector.

\subsection{Analytical Protocol}

The 46 artifacts were analyzed using Portable X-ray fluorescence (XRF) technology. Two series of analyses were performed. The first was done with a conventional analytic configuration and the second with a yellow filter (typcot filter) enhancing collection of trace element important to determine the geological provenience of the mineral. This elemental analysis was carried out with a portable Bruker Tracer III SD, using the following parameters: $45 \mathrm{kV}-11.30 \mu \mathrm{A}$. The samples were exposed 60 seconds to collect the data. This stage was done in the Archaeological Laboratory of the Pontificia Universidad Catolica del Peru in Lima.

In addition, these basic analyses were complemented with structural analysis through X-ray diffraction, using conventional and synchrotron radiation on selected samples of the collection. 
The latter analytical method was applied on six samples: three from the ceremonial sector and three from the domestic area. The samples, prepared as powder, were studied by Synchroton Xray Diffraction (SXRD) at the Argonne National Laboratory (Lemont, IL), at ambient temperature using beamline 11-BM of the Advanced Photon Source (APS) with an incident wavelength of $0.413841 \AA$ (Lee et al. 2008). The sample powders were loaded in $0.8 \mathrm{~mm}$ diameter polyamide capillaries spun at $10 \mathrm{~Hz}$ during data collection to improve powder averaging. Data was collected using the beamline's twelve $\mathrm{Si}(111)$ analyzer crystals coupled to twelve Oxford-Danfysik LaCl3 scintillators, scanning over a $2 \theta$ range of 0.8 to 50 degrees, with data points collected every $0.001^{\circ} 2 \theta$ and scan speed of $0.1^{\circ} /$ second. One sample was then analyzed by conventional X-ray diffraction (XRD) at the Crystallography Laboratory of the Physics Department at the Universidad Nacional Mayor de San Marcos in Lima. The data was collected using a Bruker D8 Focus powder diffractometer in $\theta-2 \theta$ geometry and $\mathrm{Cu} K \alpha$ radiation $\left(\lambda=1.5418 \AA\right.$ ) . Divergence slits of $1 \mathrm{~mm}$, reception slit of $0.1 \mathrm{~mm}$ and Soller slits of $2.5^{\circ}$ were used to limit the beam to the sample that was mounted on a flat sample holder. The X-ray generator was operated at $40 \mathrm{kV}$ and $40 \mathrm{~mA}$ of power and a scintillation detector was used. Data was collected between 4 and $65^{\circ}$ with a step of $0.02^{\circ}$ and data collection time of 6 seconds per step.

The analyses using XRD and SXRD are very important since they allowed identifying the presence of mineral components complementing the results from the elemental composition acquired through $\mathrm{XRF}^{9}$. In addition, they allow obtaining quantitative compositional data using the Rietveld method (Young 1993) with the Bruker AXS Topas program. ${ }^{10}$

The experimental methodology concerned a representative sample using elemental techniques (XRF), as well as structural ones (XRD and SXRD), together allowed us to acquire compositional results informing us about relating to the presence and processing of red pigments at Gramalote.

In order to determine the composition of some of the mercury-based results on the Gramalote samples, isotopic analyses were carried out on four samples. The results of the isotopic analyses of four mercury-based samples from Gramalote are published here for the first time and a brief description of the analytical technique utilized is in order. There are seven stable

\footnotetext{
${ }^{9}$ Phase identification in the samples was performed using the program EVA Copyright @ Bruker-AXS 1996-2007.

${ }^{10}$ TOPAS User's Manual, BRUKER AXS GmbH, Karlsruhe, West Germany.

DIFFRACplus; TOPAS/TOPAS R/TOPAS P; Version 3.0; Technical Reference, BRUKER AXS GmbH, Karlsruhe, West Germany.
} 
isotopes of mercury $\left({ }^{196} \mathrm{Hg},{ }^{198} \mathrm{Hg},{ }^{199} \mathrm{Hg},{ }^{200} \mathrm{Hg},{ }^{201} \mathrm{Hg},{ }^{202} \mathrm{Hg}\right.$, and ${ }^{204} \mathrm{Hg}$,). The abundance of each isotope is measured as a ratio, which is reported relative to a standard. This is standard delta $(\delta)$ notation, which, for mercury, is expressed as $\delta^{202} \mathrm{Hg}$ in the units per mil (\%o) (Blum 2011). In addition, recent research (Cooke et al. 2013) has demonstrated New World cinnabar deposits also exhibit mass-independent fractionation (MIF). Mass-independent fraction occurs when the isotopic ratio of a sample deviates above (or below) what would otherwise be predicted based upon mass alone (i.e., above or below the expected $\square^{202} \mathrm{Hg}$ signature) and is reported as $\Delta^{199} \mathrm{Hg}$ or $\Delta^{201} \mathrm{Hg}$. These values, which can be either positive or negative, represent the difference between the measured $\delta{ }^{199} \mathrm{Hg}$ and $\delta{ }^{201} \mathrm{Hg}$ values and those predicted based on MDF alone. Here we measured the $\mathrm{Hg}$ isotopic composition of cinnabar from Gramalote using continuous-flow cold vapor generation MC-ICP/MS (Nu Instruments) at Trent University. Analytical uncertainty was evaluated using replicate analyses of the UM-Almadén standard (Blum 2011) and replicate analysis of the certified standard reference materials (CRM) MESS-3 (marine sediment) and NIST 1944 (New York/New Jersey waterway sediment). The CRM were processed and analyzed in the same manner as samples. The results for these standards were indistinguishable (within uncertainty ranges) from published values (e.g., Blum and Bergquist 2007). We estimate a typical analytical uncertainty of a given isotope ratio as $2 \mathrm{SD}$ standard deviation (SD) of the measurement of the ratio in procedural standards (e.g., $\square^{202} \mathrm{Hg}$ uncertainty $=0.09 \%$ ). Four samples were also digested and measured in duplicate at different sessions. These duplicates

yielded $\square^{202} \mathrm{Hg}$ values with 2 SD uncertainty ranges spanning $\pm 0.02 \%$ to $\pm 0.56 \%$ ( $\left({ }^{202} \mathrm{Hg}\right.$ ) and $\pm 0.02 \%$ to $\pm 0.09 \%$ o ( $\left.\Delta^{199} \mathrm{Hg}\right)$.

As can be seen in Figure xx, source samples of cinnabar from Huancavelica vary in their $\delta^{202} \mathrm{Hg}$ and $\Delta^{199} \mathrm{Hg}$ ratios, but they do so predictably. A best-fit line describes this relationship with a high degree of confidence $\left(r^{2}=0.99 ; p=0.001\right)$.

\section{Results}

\subsection{Identifying the Mineral Composition of the Red Pigment at Gramalote}

In the domestic sector, two red pigments were identified. One is based on iron oxide (hematite) $\left(\mathrm{Fe}_{2} \mathrm{O}_{3}\right)$ and the other is based on mercury mineral or cinnabar (HgS) (Figures 8 and 9). The mercury mineral is always mixed with iron oxide. Interestingly, both elements are found as part of the red pigment during Phase 1 and 2 occupations but not in the latest (Phase 3) where 
the cinnabar pigment is absent. Preliminary results based on the analyzed materials indicate that during the early occupational levels of the site the cinnabar pigment is present on all the materials but the ceramics (see below).

Most of the red pigment is based on hematite which is associated with illite, a type of clay $\left[(\mathrm{K}, \mathrm{H} 3 \mathrm{O})(\mathrm{Al}, \mathrm{Mg}, \mathrm{Fe}) 2(\mathrm{Si}, \mathrm{Al}) 4 \mathrm{O} 10[(\boldsymbol{O H}) 2,(\mathrm{H} 2 \mathrm{O})]\right.$, and gypsum $\left(\mathrm{CaSO}_{4} .2 \mathrm{H}_{2} \mathrm{O}\right)$ (Figure 8). Like the hematite, the cinnabar pigment is associated with a high concentration of calcium $(\mathrm{Ca})$ (Figure 9).

Similar to the domestic area, in the ceremonial sector two pigments were found: hematite $\left(\mathrm{Fe}_{2} \mathrm{O}_{3}\right)$ and cinnabar (HgS) (Figures 10 and 11). Interestingly, the cinnabar pigment mixed with hematite was identified in Phases 2 and 3 and on ceramic objects, shells and textiles. It was not found on stone tools and carved bones.

Three pieces of cotton fabrics were also analyzed (two from the domestic sector and one from the ceremonial sector). Two of them show mercury (one from each sector of the site) mixed with iron and a high and constant concentration of lead (Figure 12). Macroscopically a thin layer of a bright grey mineral was noted, which could be responsible for this high lead concentration in the textiles.

Finally, all the analyzed samples showed trace elements which can be features of the geologic origin of the red pigment based on hematite. Basically they consist of metallic inclusions of $\operatorname{nickel}(\mathrm{Ni})$, copper $(\mathrm{Cu})$ and lead $(\mathrm{Pb})$.

\subsection{Sourcing the Provenience of the Hematite}

The traditional fishermen of Huanchaco, a modern fishing community located only $1 \mathrm{~km}$. from the Gramalote site, knew about the presence of a red pigment mine located on the northern end of the Campana Mountain, approximately $17 \mathrm{~km}$. north of the Gramalote site (Figure 1). The mine is located along the northwestern slopes of Campana Mountain at an elevation of 210 meters above sea level. It was re-discovered by Peruvian archaeologist Régulo Franco (PazCampusano 2012). The mine was visited during the summer of 2013 by two of the authors of this paper, Veronique Wright and Aldo Watanave, to take samples and perform XRF analysis (Figure 13). At present, no archaeological excavations have been carried out at this mine site, but preliminary observations around the area show the presence of scattered ceramic fragments of the Late Intermediate Period (1100 - 1470 AD). In the area of the mine there are several Initial 
Period camp-sites, suggesting that people from this period were aware of the mine (Toshihara 2002). The mine has at least two natural entries or tunnels on the walls of a dead-end ravine. At this point it is difficult to determine if the shaft entry ways are natural or if they were excavated and/or expanded by human action. The surrounding cliffs show exposed veins of red mineral, which in some instances exhibits a vivid red color (Figure 14).

Preliminary results based on three samples taken from the Campana Mountain mine indicate that this mine is not of cinnabar but it is definitely of iron oxide (hematite) (Figure 15). As is shown in Figure 15, it can be observed that the trace elements of both samples (Gramalote and the Campana Mountain mine) are almost identical. It was also interesting to determine that natural pigments from the Campana Mountain have a calcium ( $\mathrm{Ca}$ ) component like the pigments found at Gramalote. Although Calcium is a very widespread element which can derive from several sources such as sedimentary rocks, shells, sands, etc., this evidence suggests that the calcium (identified in the archaeological samples) is either from natural provenience, a result of sampling contamination and/or an added element during pigment production at Gramalote.

Based on this evidence, we propose that the Gramalote residents used the Campana Mountain deposit to extract hematite to produce their red pigment. It is possible that the Gramalote inhabitants became aware of this source during their continuous expeditions to the western slopes of the Campana Mountain to collect bromeliads (Tillandsia sp.), which were the major source of fuel for the site. It should be mentioned that Gramalote is the nearest and largest Initial Period residential settlement to this mine. Therefore, based on the abundance of hematite from this mine at and near the site, it can be argued that the Gramalote inhabitants had some sort of open access to this resource.

\subsection{Sourcing the Provenience of the Cinnabar}

The only known mercury based pigment is cinnabar (mercury sulfide or $\mathrm{HgS}$ ). In antiquity, cinnabar ore was processed by grinding and sieving to remove impurities in order to produce a bright red powder that could be mixed with an adhesive and used as a red pigment. Its color was a stronger and more vibrant red than the tones available from pigment produced from hematite. However, cinnabar deposits are much rarer than those of hematite and consequently during Prehispanic there was an important long distance trade in cinnabar (Burger and Matos 1992, Cooke et al. 2013 ). 
The geological source of cinnabar can be studied using appropriate scientific techniques. Ideally, different geological deposits of cinnabar will have chemical or isotopic differences that can be quantified with a high degree of confidence. In the Andes, efforts at sourcing have taken advantage of recent advances in the measurement of mercury isotopes and a study of Andean cinnabar by Burger and Cooke produced promising results (Cooke et al. 2013), and similar success using mercury isotopes to source cinnabar was recently achieved in the Old World as well (Emslie et al. 2014).

Traditionally, it was believed that the cinnabar encountered at Peruvian archaeological sites came from the Huancavelica mining zone in the south central highlands of Peru (Burger 1984:198; 1988:138). For decades this idea was unconfirmed since no sourcing of the cinnabar had taken place. In fact, no attempt to source Andean cinnabar was to be undertaken until 2011. It is known that geologic sources of cinnabar other than those of Huancavelica exist in the northern and central Andes, although none are comparable in size to the one in the Huancavelica area, which is acknowledged as biggest cinnabar deposit in the Western Hemisphere and one of the three or four largest cinnabar deposits in the world.

Burger and Cooke initiated a collaborative project at Yale University with the goal of sourcing Andean cinnabar through the study of mercury isotopes. The mercury isotopic measurements were made in the laboratory of Holger Hintelmann at Trent University. Highprecision measurements of mercury isotopes have afforded new opportunities to source cinnabar in both archaeological (Cooke et al. 2013) and environmental settings (reviewed in Blum 2011). The technique employed and the initial results of this pilot study have been published elsewhere (Cooke et al. 2013). In the initial study, cinnabar samples from eight geological deposits in Peru, Colombia, Bolivia, Chile and Honduras were analyzed (Cooke et al 2013 : Table 1). Multiple samples from the famous Huancavelica source were included in the study and although the isotopic signature of the source proved to be unusually heterogeneous, its patterned heterogeneity permitted it to be distinguished, with one exception, from the other New World cinnabar sources sampled (Cooke et al. 2013 : Figure 2). An isotopic analysis of 17 cinnabar samples from Peruvian archaeological sites was then compared to the analysis of the sources and the vast majority showed isotopic results consistent with the Huancavelica cinnabar deposit (Cooke et al. Figure 2). Significantly, cinnabar taken from three Inca artifacts demonstrated that 
in late Prehispanic times one or more cinnabar sources other than Huancavelica were being exploited.

Following the initial pilot project, additional archaeological samples were analyzed in 2014 (Burger et al., in press), including four archaeological samples from Prieto's excavations at Gramalote. The four cinnabar samples from Gramalote analyzed had an isotopic composition consistent with that of the Huancavelica source (Figure 16). As can be seen in Figure 16, source samples of cinnabar from Huancavelica vary in their $\delta^{202} \mathrm{Hg}$ and $\Delta{ }^{199} \mathrm{Hg}$ ratios, but they do so predictably. A best-fit line describes this relationship with a high degree of confidence $\left(\mathrm{r}^{2}=0.99\right.$; $\mathrm{p}=0.001)$.

\subsection{The Production of Red Paint at Gramalote}

One of the main goals of this research was to identify the steps in processing red paint. Therefore, special attention was taken to determine if artifacts used at different stages of the production show chemical elements added in the process. Although the pigment from the flat stones, grinding stones, bone tools, ceramic stamps and shell containers were tested, all of them showed the same composition, suggesting that at this stage no special procedure was done besides grinding the mineral and perhaps mixing the hematite with the mercury based mineral. After the minerals were grinded, it is possible that adding water and a sticky element such as animal grease were fundamental in the process of making the red paint (Figure 17). This is based on the fact that shell containers show an oily and liquid consistency, confirming that the red powder was mixed with some of the elements proposed above. Lipids are impossible to identify through XRF analysis, so further work is required to elucidate the production process of the red paint found at Gramalote. However, in this paper we are focused on the mineralogical composition of the red pigments present in this site.

The hematite obtained from the Campana Mountain mine was brought to the site in small chunks. In the same way, the cinnabar was first obtained from a non-local source (perhaps through exchange with other contemporary communities), and brought to the site in small chunks that were subsequently ground with cobbles. To grind the mineral, the Gramalote settlers used grinding stones locally known as "manos" which are medium to small sized cobbles. These stones are not common along the Gramalote coastline, so they must have been chosen and then 
brought from elsewhere. Perhaps they were brought from the Moche river bed and delta located some $10 \mathrm{~km}$ south of Gramalote (Figure 1).

The majority of the cobbles we found at Gramalote show a marked concentration of red color on one edge of the stone (Figure 3C). The mineral chunks (hematite and cinnabar) were apparently placed on flat stones locally known as batanes and then ground to a fine powder. Two types of batanes have been identified. The most common ones were the small type, mostly found in the domestic sector of the site. The second type is the large batanes, concentrated around the ceremonial sector of the site (Figure 3A-3B). The presence of cinnabar mineral on some of the batanes and grinding stones indicate that when required, the Gramalote inhabitants could add the cinnabar to their hematite red pigment. Once the hematite was ground and occasionally mixed with other red minerals, it was possibly stored as red powder in special containers (Figure 4C). It is also possible that the batanes and grinding stones used to process hematite were later used for the same purposes with cinnabar, resulting in an involuntary mixed of the two elements. However, since red paint used in final products such as cotton textiles, carved bone pendants and ceramic beads show that the pigment used is a mixed of hematite and cinnabar, it could be argued that mixing the two minerals was an intentional action (Figure 5A, 5B, 5C and 5D).

To produce red paint, the ground red powder was mixed with water and perhaps with some organic materials. The oily appearance of the pigment in the shell containers suggests that organic materials were added to make the paint. We can suggest as a working hypothesis that the Gramalote inhabitants used different kinds of organic materials such as the oil extracted from shark's liver (Prionace glauca) or from the fat of sea lions (Otaria sp.). Both species were widely consumed at the site and their grease may have been used in making red paint as other traditional communities in South America did (Lothrop 1928: 59). Another product that may have contributed to the oily texture of the red paint is a plant locally known as achiote (Bixa orellana). Achiote is well known as producing a very oily red colorant that today is still used by Amazonian communities for body painting (Lahtrap 1970: 59; Guss 1990: 64; ReichelDolmatoff 1974: 226). On the North Coast of Peru achiote is today mostly used as a food condiment and colorant. At Gramalote at least two macro-botanical remains (two dried pods) of the achiote fruit were found in the ceremonial sector. Finally, several bone spatulas were used to mix the elements and to produce the red paint (Figure 4A). 
Since we have not found large ceramic, stone or other types of containers which could have been used to mix the powder with water and oily liquids to make the red paint, we suggest that the mixing process of the red pigment powder and the other elements took place in small shell containers (Figure 4D). If so, it is possible that the red paint was mixed in shell containers for immediate use. More important, it tells us that red paint was widely and openly used by the Gramalote inhabitants but also in individual portions.

\section{Interpreting the results}

The presence of certain artifacts recovered at Gramalote suggests how the red pigment was

used. A sort of thick red paint or paste made of the red powder was used to fill incised motifs of locally made ceramic beads and to decorate incised motifs in miniature ceramic vessels. Similarly, the same product could have been used to decorate carved bone pendants, like the ones found in the burial of an adult male at the site (T-223-1). In addition, red paint was used to color textiles and cordage (Figure 5).

However, the most important use of the red paint was possibly for body paint. This conclusion arises from the large number of shell containers with evidence of finger prints, denoting a heavy and constant use of this pigment in small amounts (Figure 17). Furthermore, the presence of ceramic seal stamps with complex designs, bearing motifs not found on ceramic artifacts or textiles, suggests that they were applied to human bodies (Figure 4B). Ceramic stamps are not exclusive from Gramalote and have been found in other Initial Period sites like at Pampa de Llamas-Moxeque in the Casma valley (200 km south of Gramalote) in direct association with red pigment. Similarly, in the Chicama valley (30 km north of Gramalote) and in the highlands of the Jequetepeque valley (150 km northeast of Gramalote), ceramic stamps were used with red pigment as well during the Initial Period. Although several arguments are proposed, the most reasonable one is that these artifacts must have been used for body paint decoration (Pozorski and Pozorski 1986: 397; Burger 1992: 90).

Although more than 3000 years has passed since the abandonment of Gramalote, current traditional fishermen from the neighboring town of Huanchaco state that their ancestors used to paint their chests red before they went off on fishing expeditions (Diaz 1995). It is possible then, that ancient Gramalote fishermen decorated themselves with meaningful symbols for protection during fishing activities offshore in the ocean, as many Polynesian and Australian fishermen 
used to do in the past (Malinowski 1918). Today Amazonian hunters paint themselves with red pigments for the same purposes, as well as for protection from other animals and for good luck (Reichel-Dolmatoff 1974; Guss 1990). On the other hand, present day Amazonian females and males adolescents are painted with red motifs during the year of their transition to adult members of the society (Reichel-Dolmatoff 1974: 142; Guss 1990: 48). Married women and the heads of the family groups are also distinguished by body painting (Lathrap 1970: 184).

At Gramalote the high frequency of grinding stones, small flat stones or batanes and shell containers in virtually all the excavated houses suggests that members of the households decorated their bodies with meaningful symbols and decorative patterns. In addition, the frequent presence of anthracite bowls and plates as well as grinding stones with red pigment deposited in ritual caches throughout the site, indicate that the use of this color was important as part of domestic and community level ceremonies.

During special occasions and perhaps as part of a ceremonial calendar, the entire community could have decorated their bodies and garments with red color. Slightly later, during the late Initial Period figurines of the North Coast show evidence of body paint with red pigment on the face and chest (Figure 18). It is interesting that even today, modern fishermen from Huanchaco emphasize red color on their fishing gear because they believe it attracts fish and encourages good catches (Prieto 2015). Therefore, it is possible that, in the period of the Gramalote site, the color red could have been associated with fertility and abundance, a concept that seems to have been shared by many early human adaptations around the world (Quilter 1989; Erlandson et al. 1999; Wadley 2010; Duarte 2014).

The concentration of large flat stones or batanes around the ceremonial sector of the site points to a higher consumption of red paint during ritual activity at Gramalote. A young adult individual buried in the ceremonial facility of the site was found with a ceramic seal stamp and a bone tool to mix red paint, confirming that red paint was used during ceremonial events hosted in the ceremonial building of the site. Only one infant and an adult male were decorated with red paint on their faces at the time of death, showing that this pigment was preferred for daily ritual activities than for explicit funerary purposes. Interestingly, the red paint applied at the two death in Gramalote was always mixed with cinnabar. The choice of this coloring material supports previous studies on this pigment which point toward its toxic properties as importance in funerary contexts (Wright 2008, 2010). Mercury functions as an insecticide and preserves 
organic materials such as human flesh. The exotic character of the cinnabar at Gramalote makes it possibly a special commodity and therefore it was used for special funerary occasions.

The compositional analyses run on the samples gave us a very interesting pattern. In the southwest sector of the site (domestic sector) both hematite and cinnabar pigments were found. However, cinnabar is present in Phases 1 and 2 but not in Phase 3, coinciding with the abandonment of this sector during Phase 3. Interestingly, during Phases 1 and 2, cinnabar is present in textiles and on grinding stones, but not on the ceramic seals, miniatures of ceramic vessels or on ceramic beads.

During Phase 2, in the northeast sector of the site (ceremonial compound) cinnabar is present on a ceramic seal, ceramic beads, shells and cotton textiles but not on the flat stones or batanes and grinding stones. This evidence suggests that members of Gramalote households brought to the ceremonial compound the red pigment already grinded and ready to be used or applied on artifacts such as ceramic beads, cotton textiles, etc. In other words, it seems that they have processed the red paint in their houses and later used it on artifacts and on themselves for special occasions in the ceremonial facility of the site.

Interestingly, the number of flat stones or batanes and grinding stones during Phases 1 and 2 of Gramalote were highest in the domestic sector and get reduced during Phase 3 when compared with the ceremonial sector. By the end of the occupation (Phase 3), most of the flat stones or batanes and grinding stones were concentrated in and around the ceremonial facility, and only a few of them are present in the domestic sector. This is also true for cinnabar which, during Phase 1 and 2 of the site, was widely present in the domestic sector, but by the end of the occupation it is virtually absent from the domestic sector and only present at the ceremonial facility. This tendency indicates that the use of red pigment, though originally a domestic activity, gradually shifted to and was probably controlled at the ceremonial facility of the site. This evidence also points to the fact that cinnabar, an exotic product at Gramalote, was first widely used in domestic contexts and by the end of the occupation of the site, it was controlled by the users of the ceremonial building.

The proximity of the Gramalote fishing community to the source of hematite confirms the idea that this fishing community could have provided red pigment to other contemporary communities and ceremonial centers, at least in the Moche valley. It also opens the question of whether the Gramalote site exerted some sort of control over this resource. As this is a work in 
progress, we would like to suggest that more than controlling a resource, the Gramalote inhabitants were efficiently exploiting and processing red pigment primarily for their own needs but also using it as a valuable commodity for exchange with other contemporary sites in the valley. Perhaps through the exchange of red pigment based on hematite they gained access through intermediaries to exotic cinnabar which they could have added as a symbolic element in their own red paint.

The way in which red pigment initially was exploited, processed, and consumed at Gramalote tells us about a non-hierarchical society that developed non-subsistence activities taking advantage of local resources. However, by the end of the occupation (Phase 3) current data suggest that the production of red paint shifted from the domestic sector to the ceremonial facility of the site. This shift from a domestic production to a "ceremonial" production is closely related with the abandonment of the domestic sector during Phase 3. Although some sort of control by the users of the ceremonial facility during Phase 3 could not be ruled out, it seems that the abandonment of the domestic sector played a major role in this shift of the production location of the red paint in Gramalote. Similar situations have been observed with marine resources and the volume of ceramic concentrations during Phase 3.

In a broader perspective, the massive presence of red pigment at Gramalote, and more important the fact that it was produced there using not only local hematite ores but cinnabar from a distant region, tells us about how a supposedly highly specialized fishing settlement went beyond marine activities and diversified their activities for their own benefit. In this light, early residential settlements of the Initial Period on the Coast of Peru should be viewed as independent and dynamic social entities where a number of innovations and continuities fostered social interaction and led to the consolidation of more complex ways of life in this part of the world.

\section{Concluding Remarks}

It was possible to determine that the source of the main element use in the production of red paint was hematite $\left(\mathrm{Fe}_{2} \mathrm{O}_{3}\right)$ from a local source that was possibly collectively managed and own by the Gramalote inhabitants due to its proximity (Figure 1). The second element -but in lower quantity- that was used to make the red pigment is cinnabar, perhaps cinnabar $(\mathrm{HgS})$.

Isotopic analysis determined that the cinnabar pigment found mixed with hematite based pigment came from an ore that had been mined in the cinnabar geological deposit in 
Huancavelica, located at roughly 4,000 meters above sea level and some 730 kilometers to the southeast of the shoreline community of Gramalote. As noted, this is the earliest documented case of cinnabar consumption at an Andean archaeological site. It is also the first archaeological evidence for the early Initial Period exploitation of the Huancavelica mining zone and the long distance distribution of the bright red pigment produced by processing the cinnabar ore.

It is plausible that the Gramalote inhabitants obtained this exotic element through direct contact with contemporary highland communities who had in turn access with settlements associated with the people who directly exploited the cinnabar ore at Huancavelica. In short, during the early Initial Period, cinnabar may have been passed hand by hand along an interconnected network of independent coastal and highland communities which were constantly exchanging subsistence products and other manufactured goods. In exchange, the Gramalote inhabitants could have traded their important marine products such as dried and/or salted fish, dried seaweed and sea salt, among others which are known to be valued by highland communities (Burger 1985).

Although we have not run the samples yet, the presence of red pigment very possibly based on hematite found at the neighboring and contemporary inland ceremonial centers of Caballo Muerto, Menocucho and La Constancia (all in the Moche valley; see Figure 1), suggest that the Gramalote inhabitants may have distributed the red pigment in the form of red powder to all these settlements. If this is true, a small fishing settlement provided an important and valuable good which was used in many domestic and public rituals during the Initial Period. We should consider the possibility that during this early period, small-scale residential sites in the Central Andes were involved in some sort of household industries which means household-based intermittent non-subsistence activities based on local available resources for local use and to count as an additional commodity at the time of trading food products with peer communities or larger settlements (Brumfiel and Nichols 2008).

Mineralogical and isotopic analysis helped us not only to identify the main elements used in the production of the red paint but also to sourcing its provenance. What it was impossible to determine through structural analyses is an important step in the production of this pigment which is the possibility that animal grease and water were added on its production. Future analysis involving gas chromatography, are needed to clarify this important step in the process of producing red pigment. 
Based on the small containers where the red paint was poured and then used, it seems that it was mainly used for body decoration, aid by bone spatulas, ceramic stamps, cotton bolls and their hands. Indeed, finger prints have been left on the shell containers (Figure 16). The uses of shell containers is seems to be an old tradition that could have been started during the Middle Preceramic period in the Central Coast of Peru (Quilter 2014: 73). In addition, red paint was an important part of domestic rituals and communal ceremonies. It is interesting that contemporary Amazonian groups consider body painting and decorating utilitarian objects with red paint as a cautionary protection against evil spirits and "to humanize" themselves as well as their daily artifacts (Guss 1990: 63). Therefore it is very possible that the Gramalote inhabitants used the red paint on a daily basis as well as for special occasions as part of a ritual calendar. Due to the fact that red color is considered among traditional societies as representing blood, fertility and social continuity, it may have been the intention to recreate these concepts in the Gramalote's ideology.

\section{Acknowledgements}

The Gramalote Archaeological Project was supported by the Albers Funds of the Department of Anthropology and the Doctoral Dissertation Fieldwork Grant of the MacMillan Center both at Yale University. This project was also made possible thanks to the Wenner-Gren Foundation (Dissertation Fieldwork Grant \#8427), the National Geographic Society/Waitt Grants Program (Grant \# W188-11) and the Sigma Xi Research Grants (Grant \# G20110315156259). The authors of this article would like to express their acknowledgements to Dr. Luis Jaime Castillo, director of the San Jose de Moro Laboratory at the Pontificia Universidad Catolica del Peru, who led us in working with the $\mathrm{x}$-ray fluorescence equipment of his laboratory. Use of the Advanced Photon Source at Argonne National Laboratory was supported by the U. S. Department of Energy, Office of Science, Office of Basic Energy Sciences, under Contract No. DE-AC02-06CH11357. We wish to express our gratitude to Holger Hintelmann for his role in the isotopic analysis of Andean cinnabar. The authors of this paper would like to acknowledge Dr. Anne Underhill and Dr. Tom Fenn at the Department of Anthropology at Yale University for reading preliminary versions of this manuscript. 


\section{References}

Allison, M., B. Arriaza, V. Standen, G. Focacci, M. Rivera and J. Lowestein

1984 Chinchorro, momias de preparacion complicada: metodos de preparacion. Chungara 13:155-173.

Altamirano, A., I. Salvatierra and G. Prieto

2012 3, 000 year-old Chondrichtyan remains from Pampas Gramalote: An ancient fishing village from northern Peru. Paper presented at the III Encuentro Colombiano sobre Condictrios, Santa Marta, Colombia.

Alva, I.

2014 Ventarron y Collud. Origen y auge de la civilizacion en la costa norte del Peru. Proyecto Especial Naylamp Lambayeque, Lambayeque.

Alva, W.

1986 Las Salinas de Chao. Asentamiento Temprano en el Norte del Peru. Materialien zur Allgemeinen und Vergleichenden Archaologie, Band 34. Kommission fur Allgemeine und Vergleichende Archaologie, Munich.

Bird, J. B., J. Hyslop and M. Dimitrijevic

1985 The Preceramic Excavations at the Huaca Prieta, Chicama Valley, Peru 62, Part I. American Museum of Natural History, New York.

Blum, J. D.,

2011 Applications of stable mercury isotopes to biogeochemistry. Springer: Berlin, 2011; 229245.

Blum, J. D and B.A. Bergquist,

2007 Reporting of variations in the natural isotopic composition of mercury. Anal. Bioanal. Chem. 388: 353-359.

Brumfiel, E. and D. Nichols

2008 Bitumen, Blades, and Beads: Prehispanic Craft Production and the Domestic Economy. Archaeological Papers of the American Anthropological Association 19(1):239-251.

Burger, R.

1984 The prehistoric occupation of Chavín de Huántar, Peru. University of California publications in anthropology. University of California Press, Berkeley

1985 Concluding Remarks: Early Peruvian Civilization and its Relation to the Chavin Horizon. In Early Ceremonial Architecture in the Andes, edited by C. Donnan, pp. 269-289. Dumbarton Oaks Research Library and Collection, Washington, DC.

1988 Unity and heterogeneity within the Chavin Horizon. In Peruvian Prehistory, edited by R. W. Keatinge, pp. 99-144. Cambridge University Press, Cambridge, MA.

1992 Chavin and the origins of Andean civilization. Thames and Hudson, London. 
Burger, R. and R. Matos

2002 Atalla: A Center on the Periphery of the Chavín Horizon. Latin American Antiquity 13(2):153-177.

Burger, R. and L. Salazar-Burger

1991 The Second Season of Investigations at the Initial Period Center of Cardal, Peru. Journal of Field Archaeology 18(3):275-296.

2009 Investigaciones Arqueologicas en Mina Perdida, valle de Lurin. In Arqueologia del Periodo Formativo en la cuenca baja de Lurin, edited by R. Burger and K. Makowski, pp. 37-58. Fondo Editorial PUCP, Lima.

Burger, R., K.E. Lane and C. Cooke

(in press) Ecuadorian Cinnabar and the Pre-Hispanic Trade in Vermilion Pigment: Viable Hypothesis or Red Herring? Latin American Antiquity (in press).

Chapdelaine, C. and V. Pimentel

2008 Personaje de Alto Rango en San Juanito, Valle del Santa. In Señores de los reinos de la luna, edited by K. Makowski, pp. 248-253. Banco de Credito del Peru, Lima,.

Chauchat, C., E. Wing and S. Uceda

2006 Prehistoria de la costa norte del Perú : el Paijanense de Cupisnique. Instituto Frances de Estudios Andinos, Lima.

Cooke Colin, H. H., Jay J. Ague, Richard Burger, Harald Biester, Julian P. Sachs and a. D. R. Engstrom

2013 Use and Legacy of Mercury in the Andes. Environmental Science \& Technology 47(9):4181-4188.

Diaz, W.

1995 Tradiciones Huanchaqueras II. Colegio Particular Claretiano, Trujillo.

Duarte, C.

2014 Red Ochre and Shells: clues to human evolution. Trends in Ecology and Evolution 29(10):560-565.

Emslie, S.D.; Brasso, R.; Patterson, W.P.; Carlos Valera, A.; McKenzie, A.; Maria Silva, A.;

Gleason, J.D.; Blum, J.D.

2015 Chronic mercury exposure in Late Neolithic/Chalcolithic populations in Portugal from the cultural use of cinnabar Nature Scientific Reports 5:14679

Engel, F.

1963 A Preceramic Settlement on the Central Coast of Peru: Asia, Unit I Transactions of the American Philosophical Society, Philadelphia.

Erlandson, J., J. Robertson and C. Descantes 
1999 Geochemical Analysis of Eight Red Ochres from Western North America. American Antiquity 64(3):517-526.

Feldman, R.

1980 Aspero, Peru: Architecture, Subsistence Economy and other artifacts of a Preceramic Maritime Chiefdom. Unpublished Ph.D dissertation, Department of Anthropology, Harvard University, Cambrige, MA.

Guss, D.

1990 To Weave and Sing. Art, Symbol and Narrative in South American Rain Forest. University of California Press.

Julien, M., Lavallee, D. and M. Dietz

1981 Les sépultures préhistoriques de Telarmachay, Junín-Pérou. Bulletin de l'Institut francais d'études Andins 10(1-2): 85-100.

Lathrap, D.

1970 The Upper Amazon. Ancient Peoples and Places. Praeger Publishers, United States of America.

Lee, P., D. Shu, M. Ramanathan, C. Preissner, J. Wang, M. Beno, R. Von Dreele, L. Ribaud, C. Kurtz, S. Antao, X. Jiao and B. Toby

2008 A twelve-analyzer detector system for high-resolution powder diffraction. Journal of Synchrotron Radiation 15:427-432.

Lothrop, S.

1928 The Indians of Tierra del Fuego. Museum of the American Indian, Heye Foundation, New York.

Lynch, T.

1980 Guitarrero Cave: Early Man in the Andes. . Academic Press, New York.

Malinowski, B.

1918 Fishing in the Trobriand Islands. Royal Anthropological Institute of Great Britain and Ireland 18:87-92.

Paz-Campusano, O.

2012 Moches habrían extraído cinabrio de mina preincaica hallada cerca de cerro Campana. Agencia Andina. Lima.

Pozorski, S. and T. Pozorski

1979a Alto Salaverry: A Peruvian Coastal Site. Annals of Carnegie Museum 48:337-375.

1979b An Early Subsistence Exchange System in the Moche Valley, Peru. Journal of Field Archaeology 6(4):413-432. 
1986 Recent Excavations at Pampa de las Llamas-Moxeke, a Complex Initial Period Site in Peru. Journal of Field Archaeology 13(4):381-401.

1987 Early settlement and subsistence in the Casma Valley, Peru. 1st ed. University of Iowa Press, Iowa City.

Pozorski, T.

1976 Caballo Muerto: A Complex of Early Ceramic Sites in the Moche Valley, Peru. Unpublished Ph.D dissertation, Department of Anthropology, The University of Texas at Austin, Austin, Texas.

Prieto, G.

2014 The Early Initial Period Fishing Settlement of Gramalote, Moche Valley: A Preliminary Report. Peruvian Prehistory 1(1):1-46.

2015 Gramalote: Domestic Life, Economy and Ritual Practices of a Prehispanic Maritime Community. Unpublished Ph.D. Dissertation, Department of Anthropology, Yale University, New Haven, CT.

Quilter, J.

1989 Life and death at Paloma : society and mortuary practices in a preceramic Peruvian village. 1st ed. University of Iowa Press, Iowa City.

2014 The Ancient Central Andes. Routledge World Archaeology. Routdledge, London and New York.

Ravines, R. and W. Isbell

1975 Garagay : sitio ceremonial temprano en el valle de Lima. Revista del Museo Nacional 41:253-275.

Reichel-Dolmatoff, G.

1974 Amazonian Cosmos. The Sexual and Religious Symbolism of the Tukano Indians. The University of Chicago Press, Chicago.

Rick, J.

1983 Cronología, clima y subsistencia en el precerámico peruano. Instituto Andino de Estudios Arqueologicos, Lima.

Rosas, H. and R. Shady

2005 Pacopampa : un centro formativo en la sierra nor-peruana. Arqueologia y Sociedad 16:11-62.

Salazar, D., D. Jackson, J. L. Guendon, H. Salinas, D. Morata, V. Figueroa, G. Manríquez and V. Castro

2011 Early Evidence (ca. 12,000 BP) for Iron Oxide Mining on the Pacific Coast of South America. Current Anthropology 52(3):463-475.

Salazar, D., J. Salinas, L. Guendon, D. Jackson and V. Figueroa 
2013 Hunter- gatherer-fisher mining during the archaic period in coastal northern Chile. In Mining and quarrying in the ancient Andes: sociopolitical, economic and symbolic dimensions, edited by K. Vaughn and N. Tripevich, pp. 137-156. Springer, New York.

Shady, R.

1997 La ciudad sagrada de Caral : Supe en los albores de la civilización en el Perú Universidad Nacional Mayor de San Marcos, Fondo Editorial, Lima.

Stothert, K. E.

1985 The Preceramic Las Vegas Culture of Coastal Ecuador. American Antiquity 50(3):613637.

Toshihara, K.

2002 The Cupisnique Culture in the Formative Period World of the Central Andes, Peru. Unpublished Ph.D dissertation, Department of Anthropology, University of Illinois at Urbana-Champaign, Urbana, Illinois.

Vaughn, K., V. Gijseghem, M. Linares and J. Eerkens

2013a Mineria de Hematita en la Costa Sur del Peru: Investigaciones Arqueologicas en Mina Primavera. Chungara 45(1):131-142.

Vaughn, K., H. Van Gijseghem, V. H. Whalen, J. Eerkens and M. Linares

2013b The organization of mining in Nasca during the Early Intermediate Period: Recent Evidence from Mina Perdida. In Mining and quarrying in the ancient Andes: sociopolitical, economic and symbolic dimensions, edited by K. Vaughn and $\mathrm{N}$. Tripevich, pp. 157-182. Springer, New York.

Vaughn, K., M. Grados, J. Eerkens and M. Edwards

2007 Hematite mining in the ancient Americas: Mina Primavera, A 2,000 year old Peruvian mine. Journal of Mineralogy 59(12):16-20.

Wadley, L.

2010 Cemented ash as a receptacle or work surface for ochre powder production at Sibudu, South Africa, 58,000 years ago. Journal of Archaeological Science 37(10):2397-2406.

Wright, V.

2008 Étude de la polychromie des reliefs sur terre crue de la Huaca de la Luna Trujillo, Pérou. British Archaeological Reports (BAR S1808), Paris Monographs in American Archaeology 21. Archaeopress, Oxford.

2010 Pigmentos y tecnología artística mochica: una nueva aproximación en la comprensión de la organización social, Contextos, materiales e identidades en la arqueología Mochica. Boletin del Instituto Frances de Estudios Andinos 39(2):299-330.

Young, R.

1993 The Rietveld Method. International Union Crystallography. Oxford University Press, New York. 


\section{Zoubek, T. A.}

1998 The initial period occupation of Huaca El Gallo/Huaca La Gallina, Viru Valley, Peru and its implications for Guanape Phase social complexity. Unpublished Ph.D. dissertation, Department of Anthropology, Yale University, New Haven.

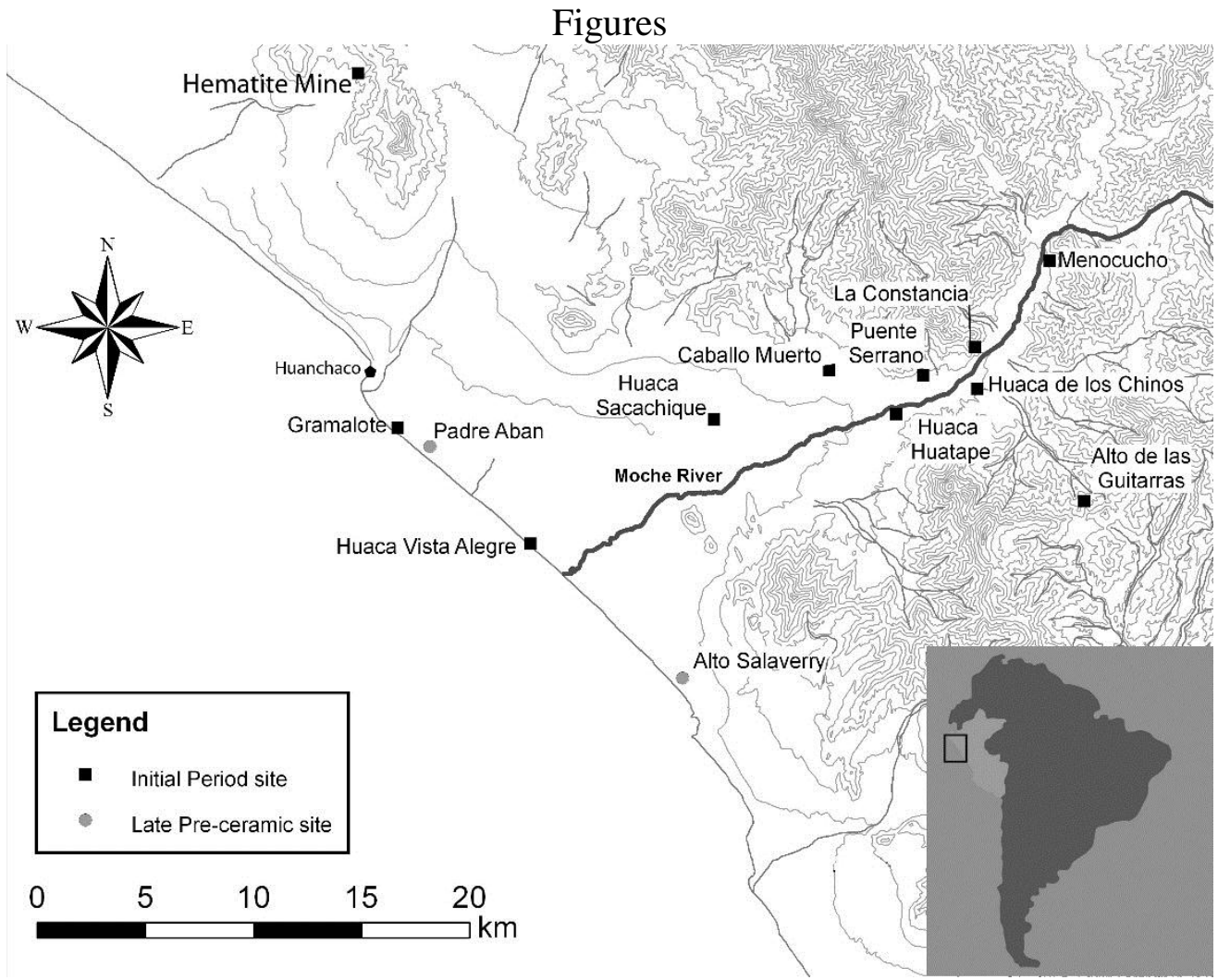

Figure 1. Map of the Moche Valley, North Coast of Peru indicating the location of Gramalote and other sites mentioned in this paper. 


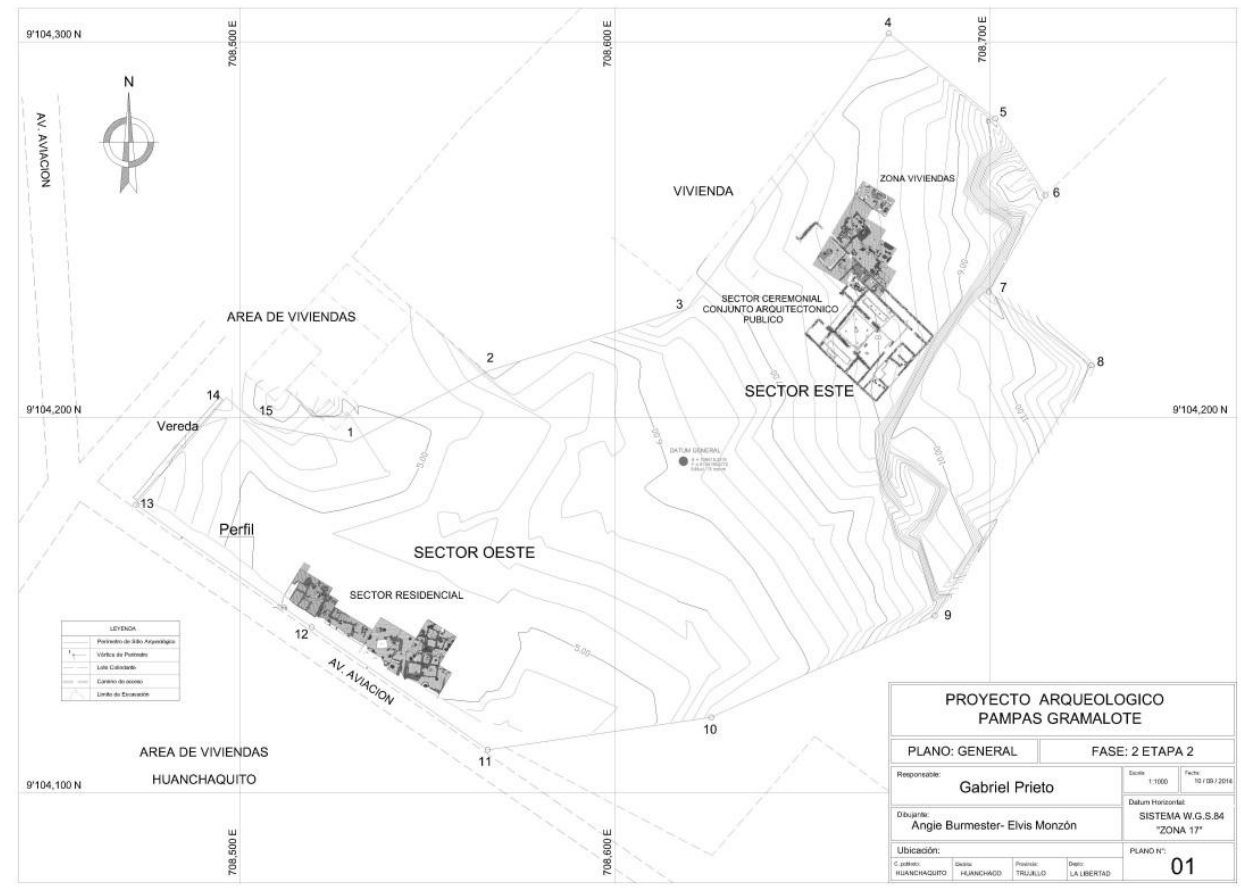

Figure 2. Map of the Gramalote archaeological site indicating its sectors and its excavated areas.
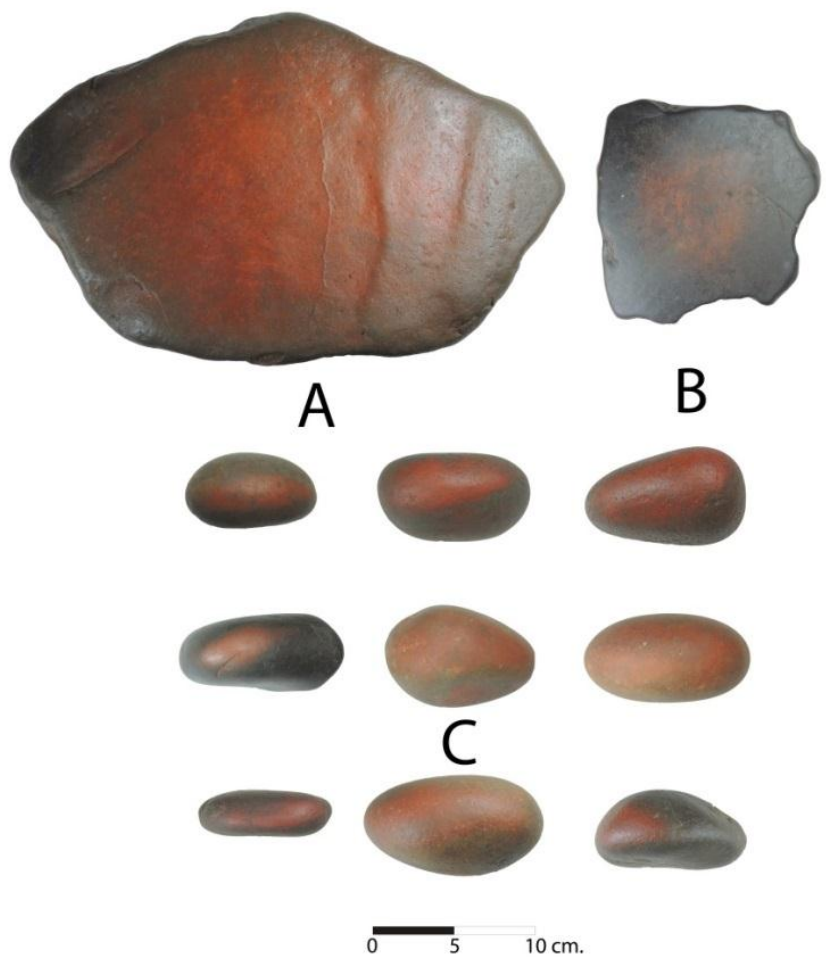

B
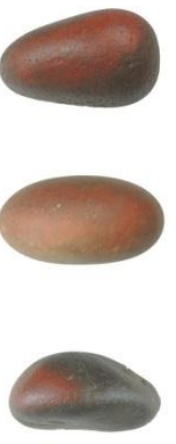

Figure 3. (A) Large flat stone; (B) small flat stone; (C) grinding stones. 


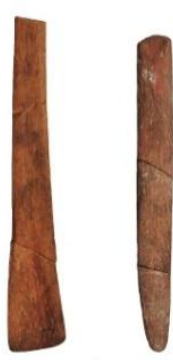

A

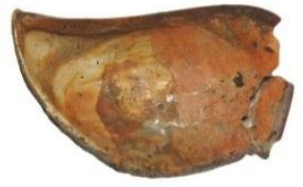

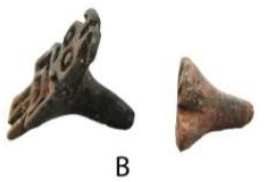

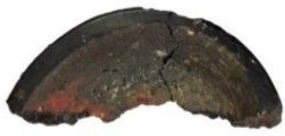

C

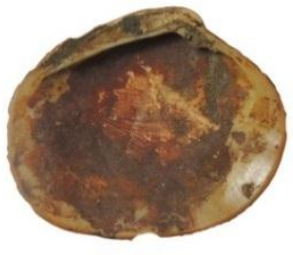

$10 \mathrm{~cm}$.

Figure 4. (A) Bone spatulas used to mix the red pigment; (B) Ceramic seal stamps used to apply designs with red pigment; (C) fragment of an anthracite container with red paint and (D) shells containers.

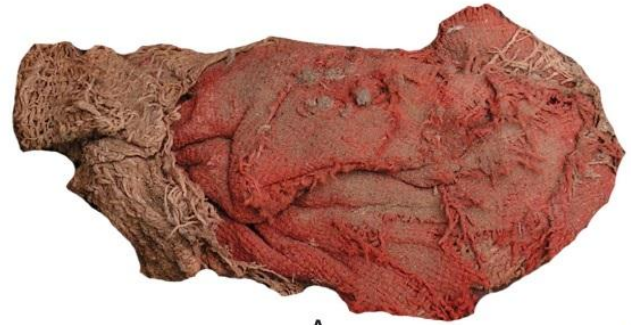

A

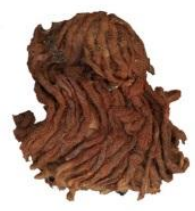

B

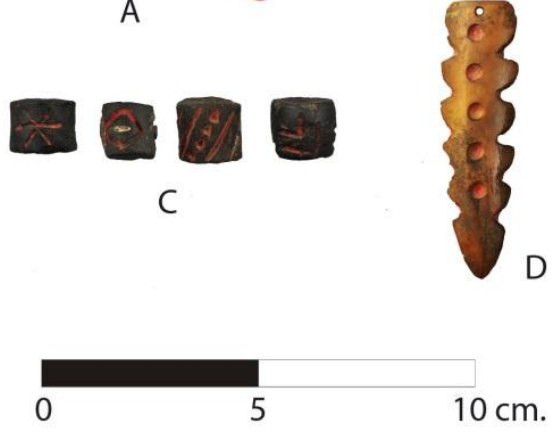

Figure 5. (A) Piece of cotton fabric dyed with red pigment; (B) Tassel painted with red pigment; (C) ceramic beads decorated with post-firing red pigment and (D) bone pendant decorated with red paint. 


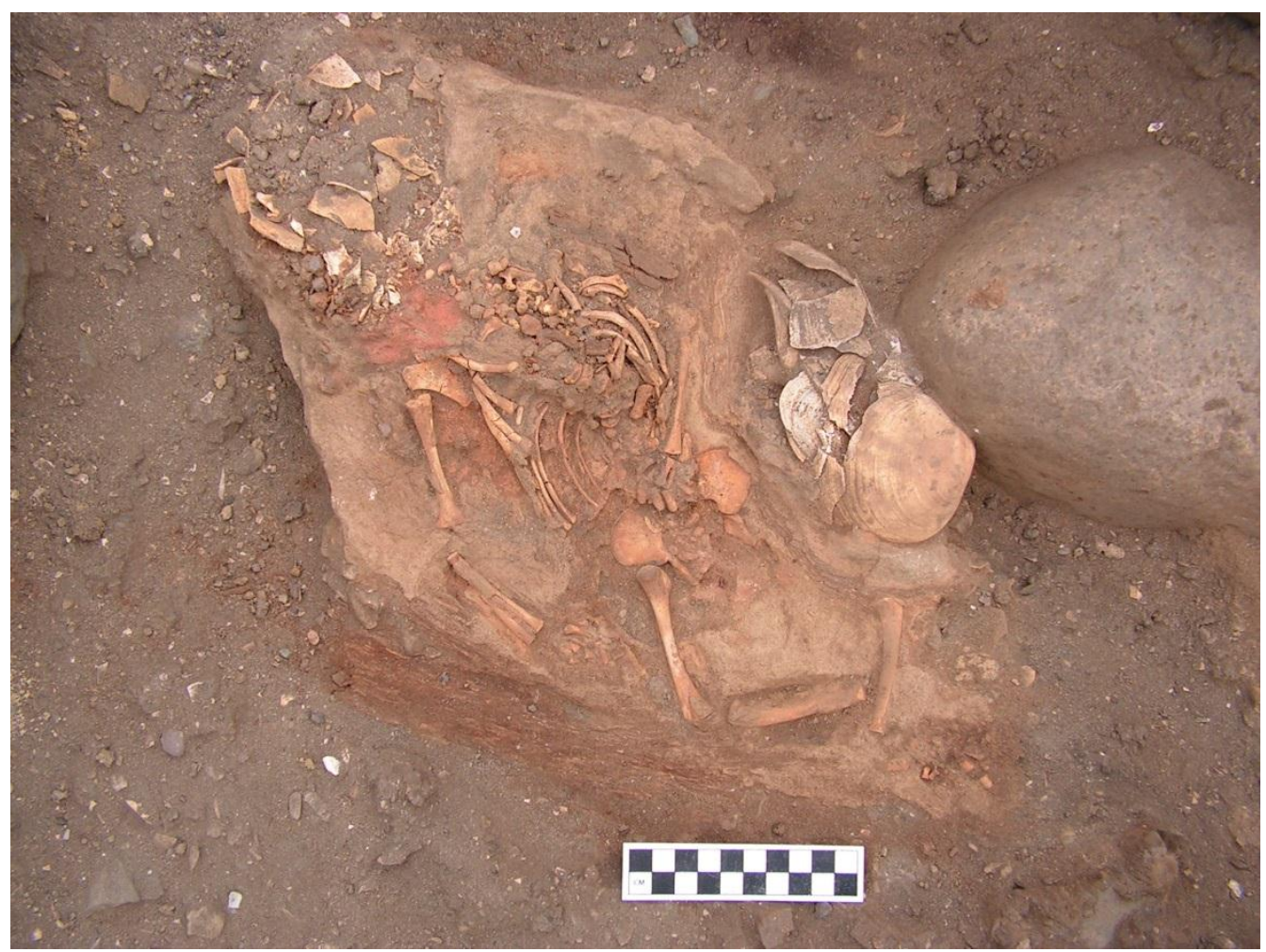

Figure 6. Burial T-201, infant found in the open space or plaza of the southwest domestic sector. Note the red paint in the lower jaw area.

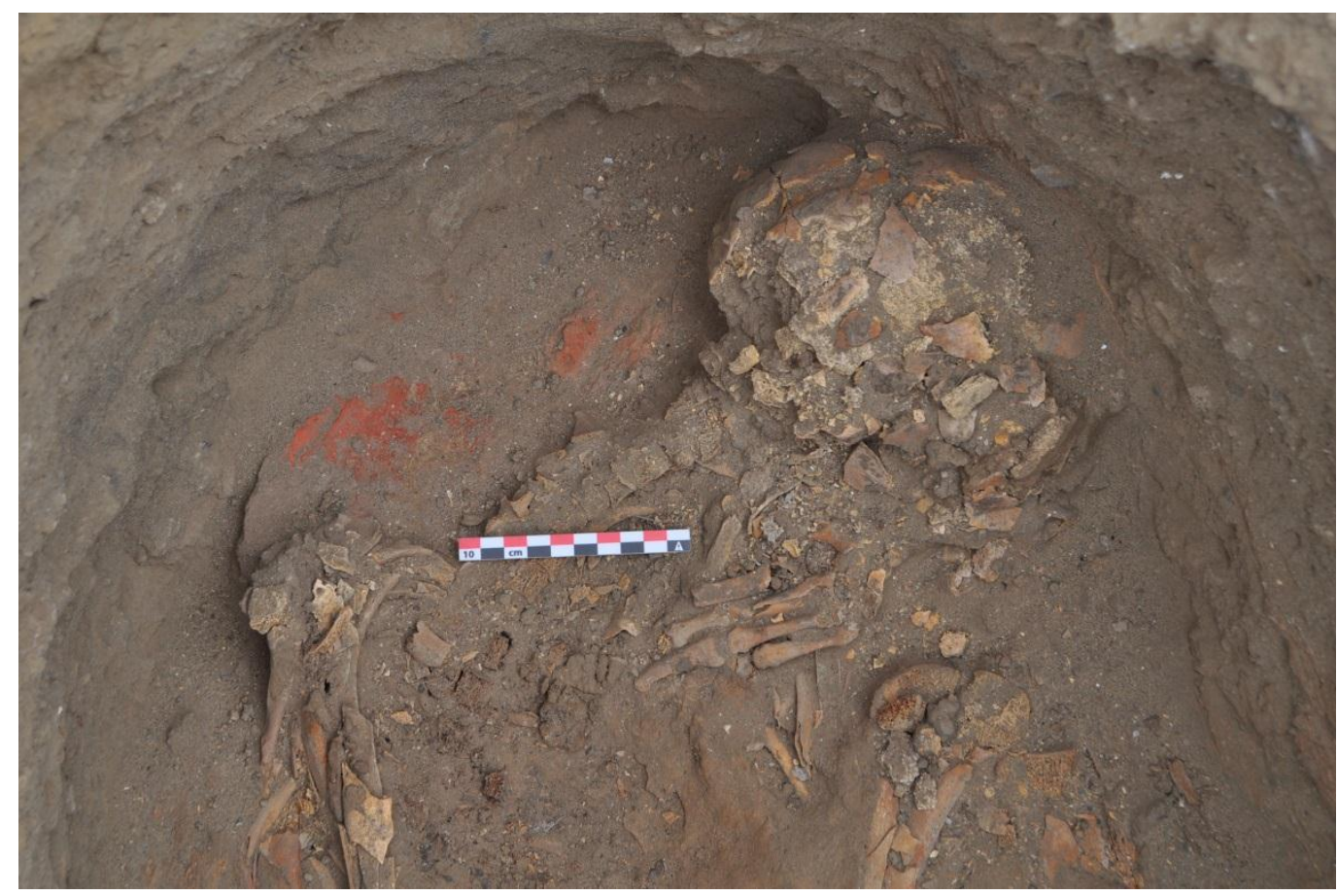

Figure 7. Red paint associated with burial T-306. Note that the pigment is located on the left side of the skull. 


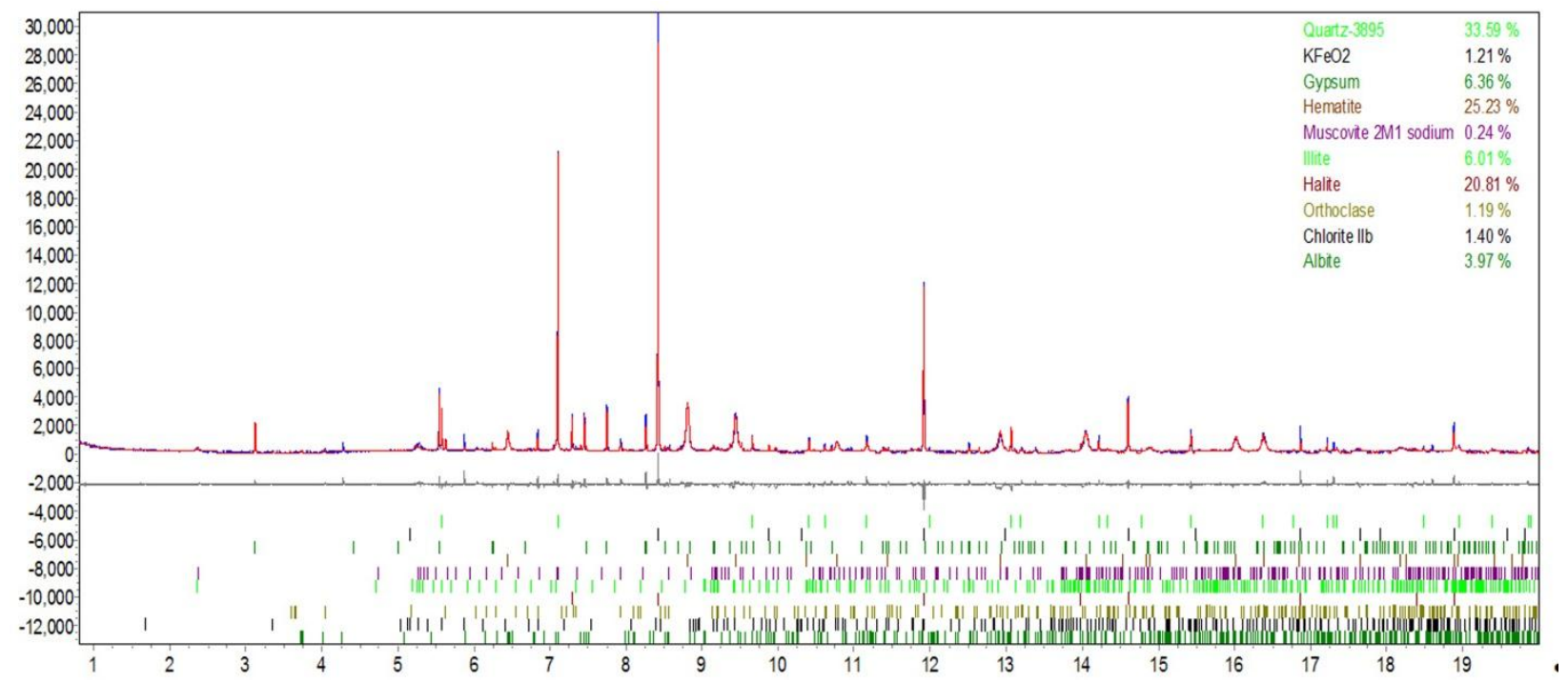

Figure 8. SXRD analysis and Rietveld method of the red pigment based primarily on hematite found on a shell container, northeast sector of Gramalote.

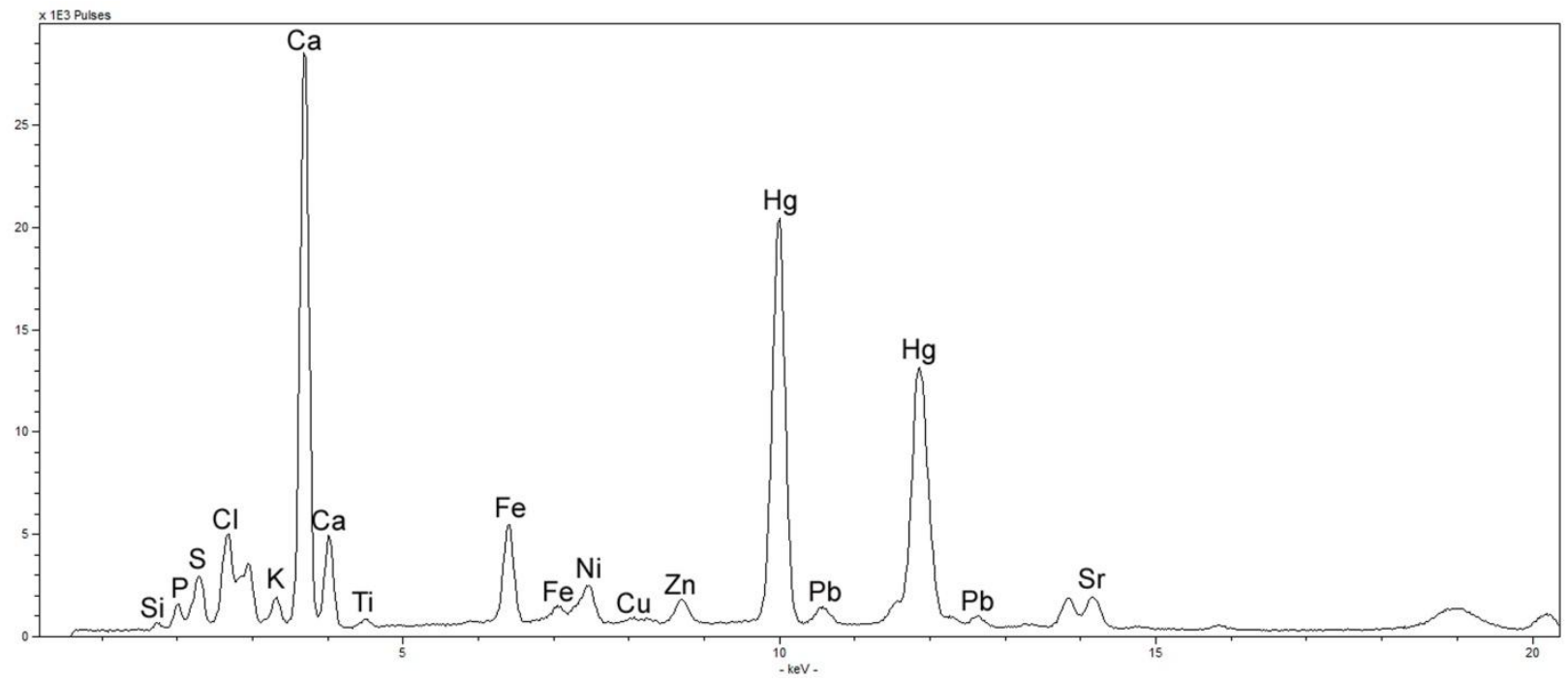

Figure 9. XRF analysis of the red pigment adhered on a bone tool found in a funerary context at Gramalote. Note the high presence of mercury $(\mathrm{Hg})$. 

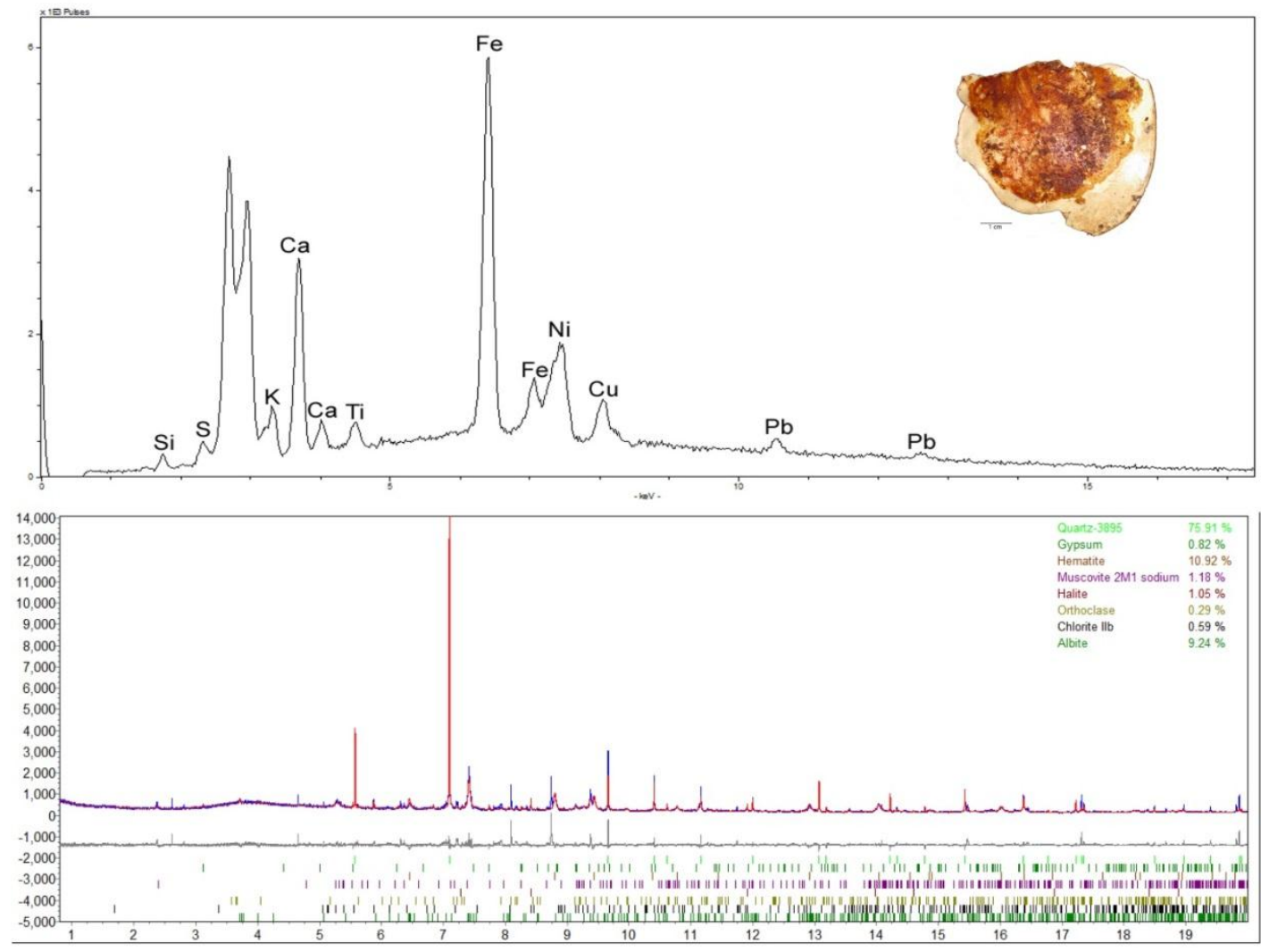

Figure 10. XRF (1), high concentration of iron $(\mathrm{Fe})$ responsible of the red color, identified as hematite $\left(\mathrm{Fe}_{2} \mathrm{O}_{3}\right)$ based on the measurements of SXRD and Rietveld method (2).
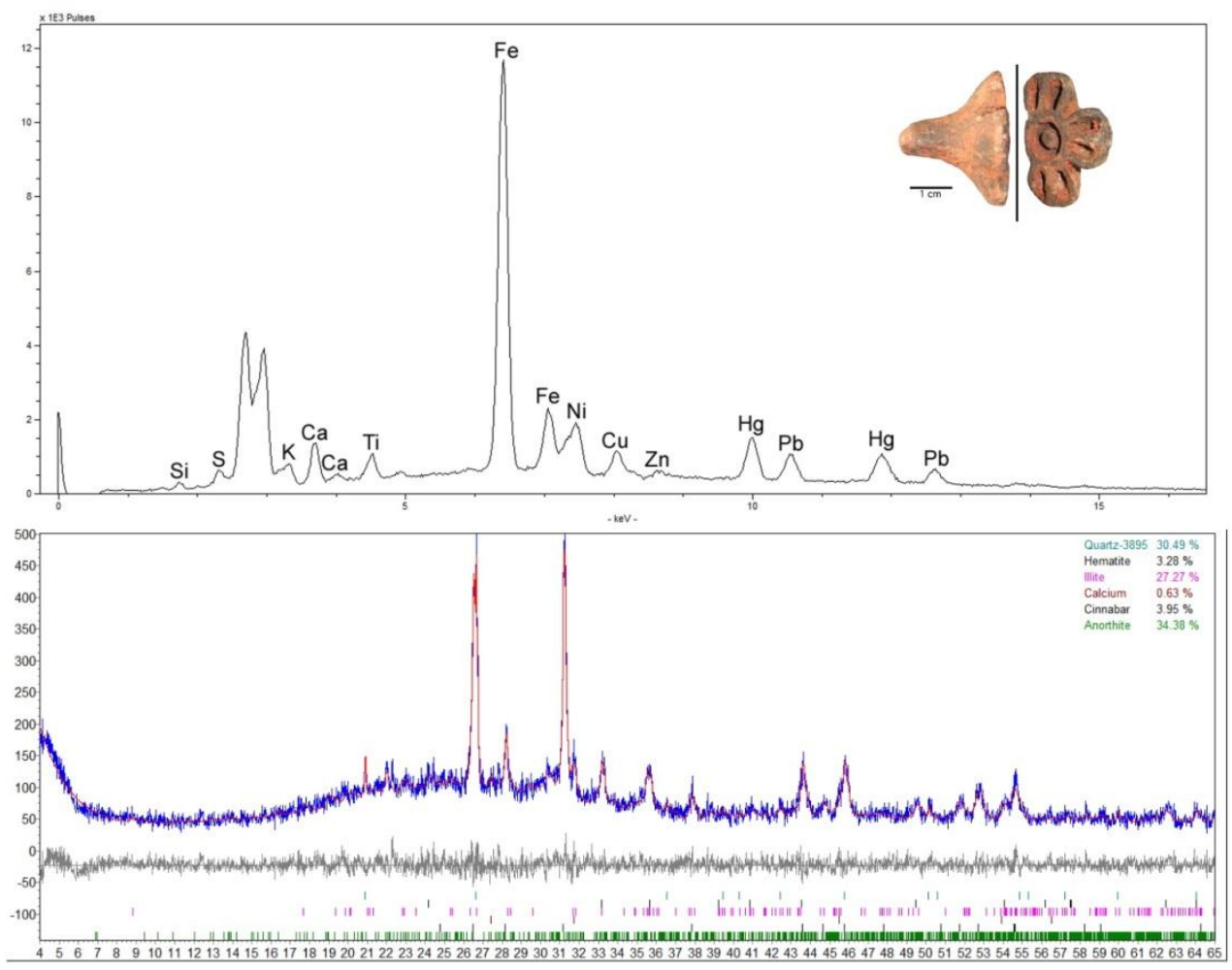
Figure 11. Red pigment adhered on a ceramic stamp seal found in a funerary context. XRF (1) shows a consistent concentration of mercury $(\mathrm{Hg})$ identified as cinnabar $(\mathrm{HgS})$ based on the measurements of XRD and the Rietveld method (2).

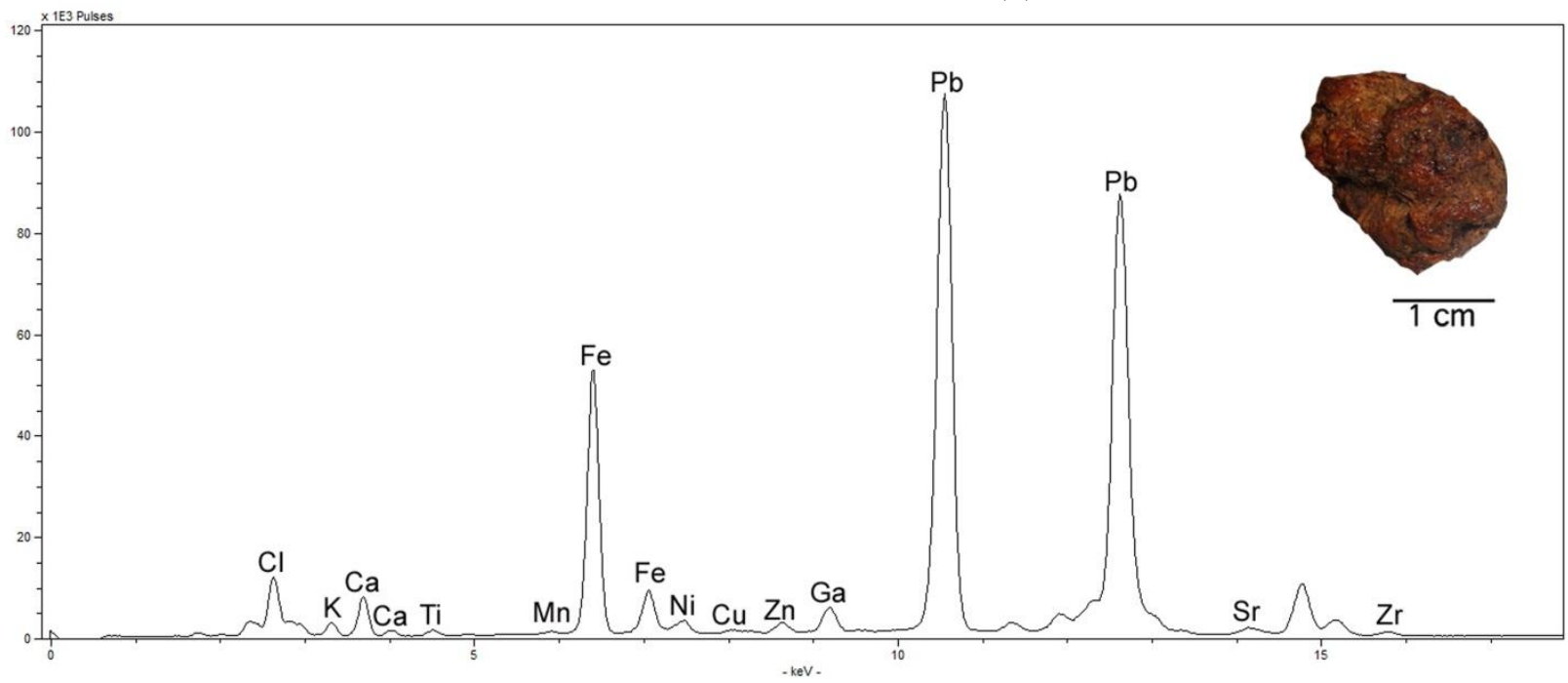

Figure 12. XRF analysis of a textile fragment found in the residential sector of the site. It has a large concentration of lead $(\mathrm{Pb})$.

\begin{tabular}{|c|c|c|c|}
\hline Sample code & Picture & Location & $\begin{array}{c}\text { Elemental composition } \\
\text { of the colorant element }\end{array}$ \\
\hline Red 1 & & $\begin{array}{c}\text { Red pigment vein } \\
\text { located in front of } \\
\text { the mine entrance }\end{array}$ & Iron oxide \\
\hline Red 2 & & $\begin{array}{c}\text { Ground red pigment } \\
\text { found on a stone } \\
\text { in front of } \\
\text { the mine entrance }\end{array}$ & Iron oxide \\
\hline Red 3 & & $\begin{array}{c}\text { Intense red pigment's } \\
\text { stain identified as } \\
\text { "mercury" by the } \\
\text { local inhabitants }\end{array}$ & Iron oxide \\
\hline
\end{tabular}

Figure 13. Samples taken from the Campana mountain mine. 


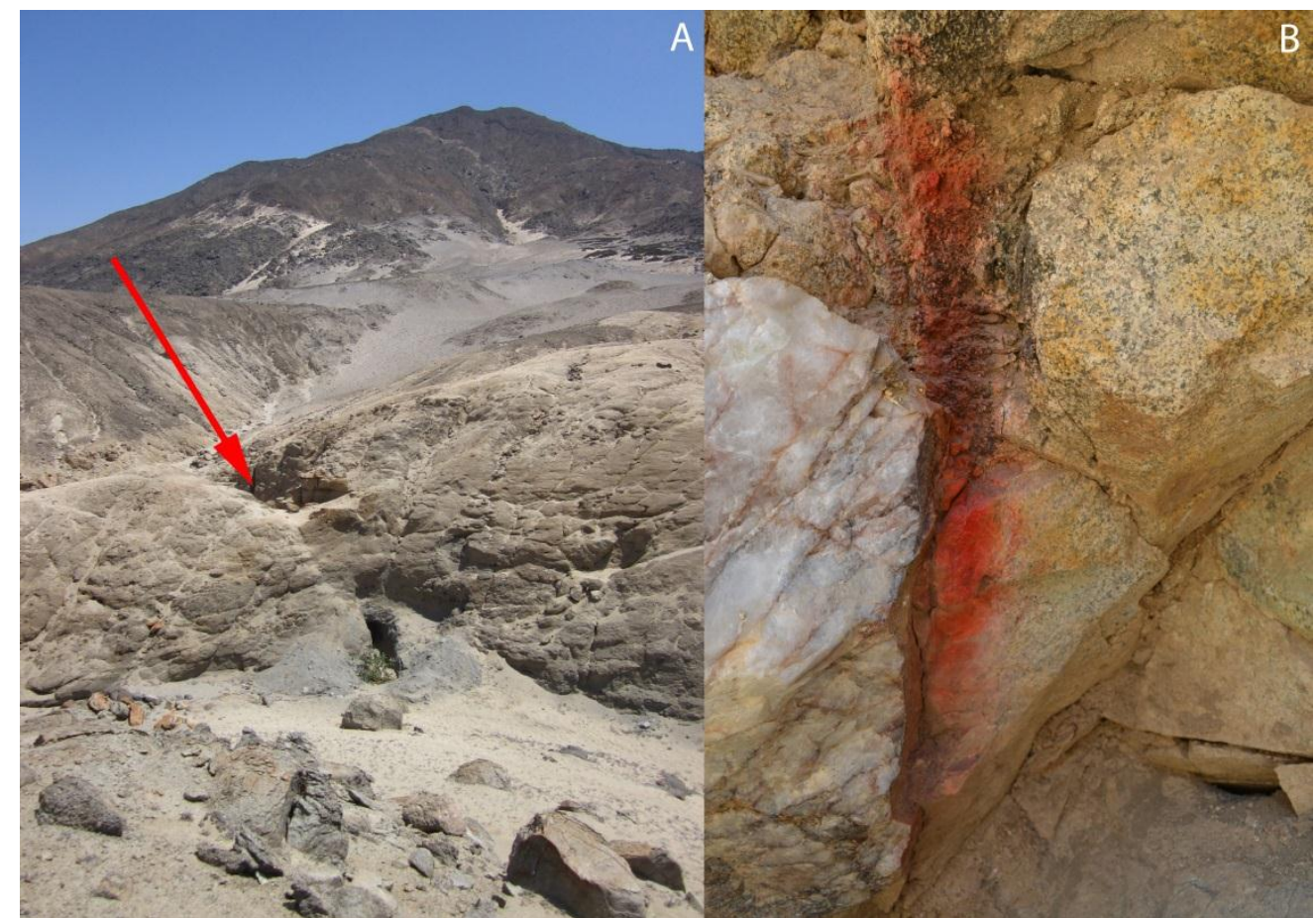

Figure 14. (A) Hematite mine of the Cerro Campana mountain, located $17 \mathrm{~km}$. from the Gramalote site;

(B) Vein of hematite in the same mine.

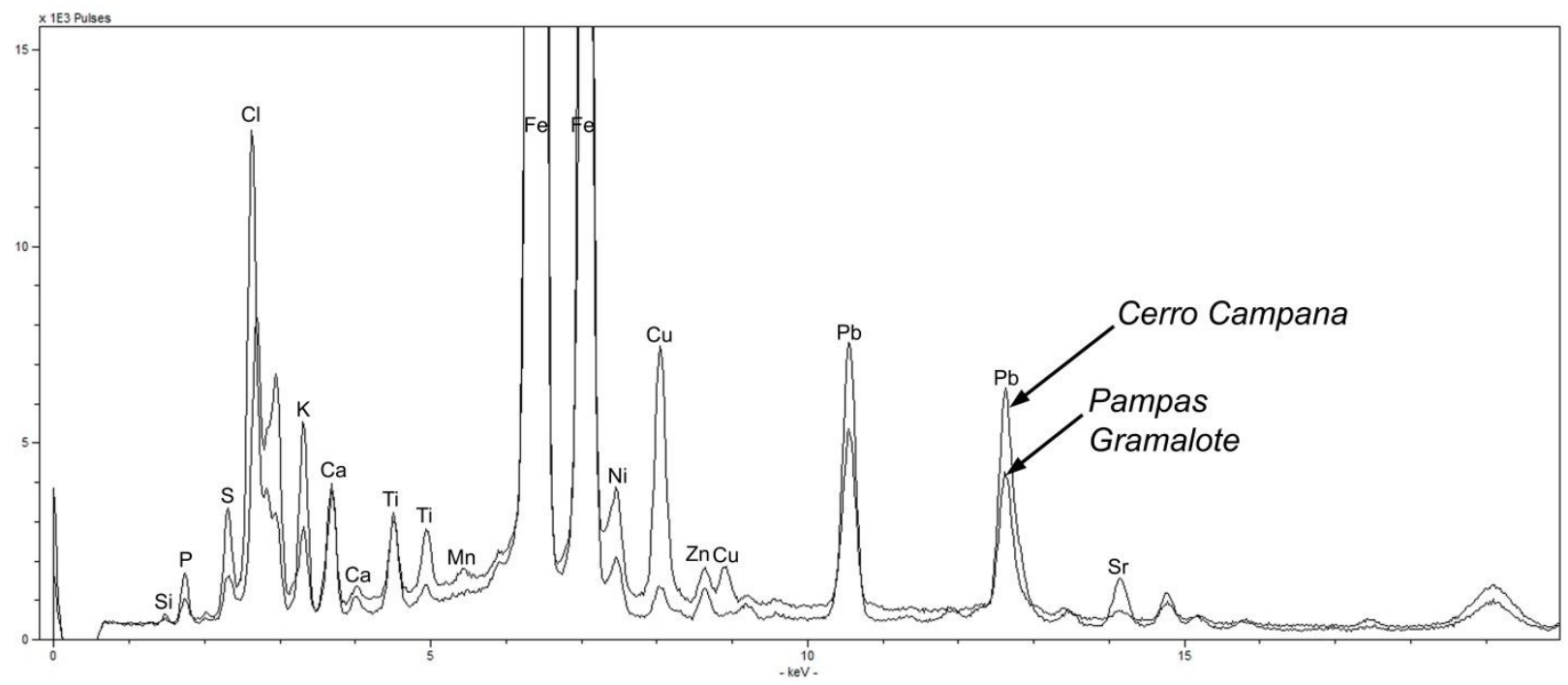

Figure 15. Elemental spectra acquired by XRF from a sample of Gramalote (Phase 1) and one of the samples from the Campana mountain mine. Note the similarities on the presence of metallic trace elements like nickel, copper zinc and lead. It also shows the high concentration of calcium on both samples. 


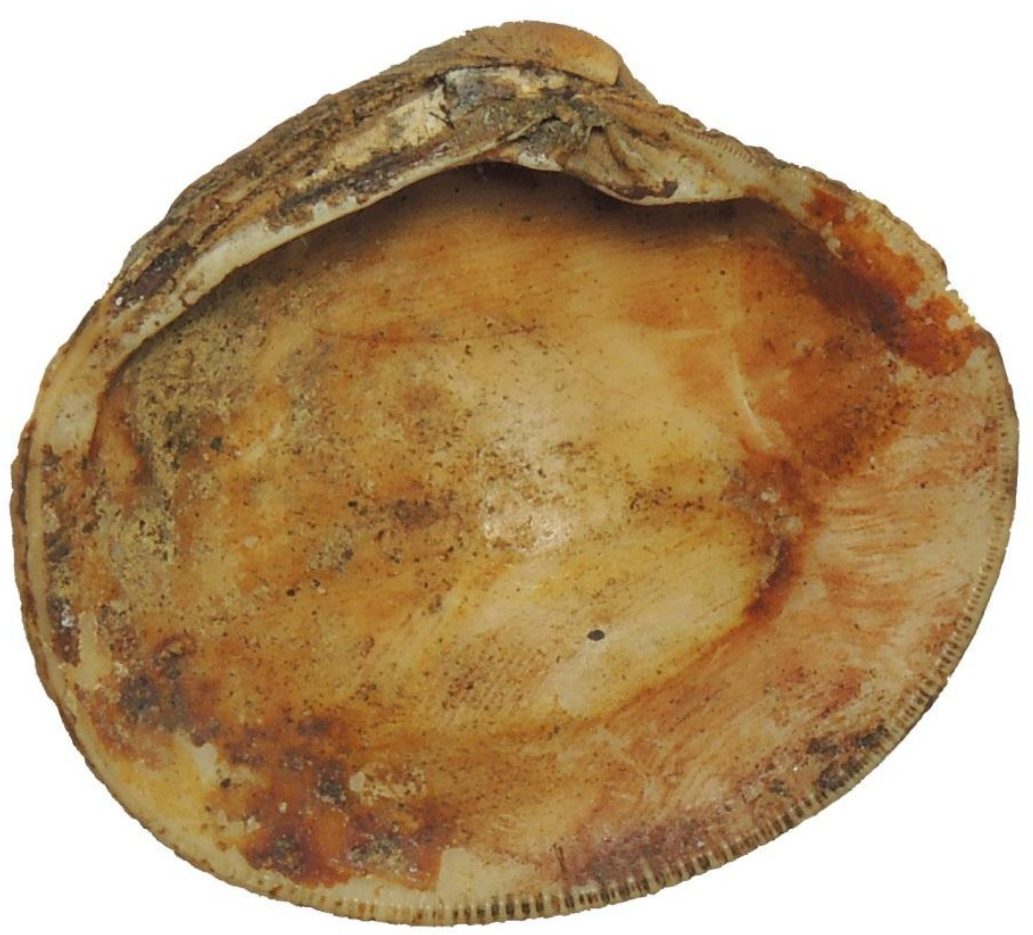

Figure 16. Shell (Protothaca thaca) container for red paint. Note the oily consistency of the paint and the traces of finger prints. 


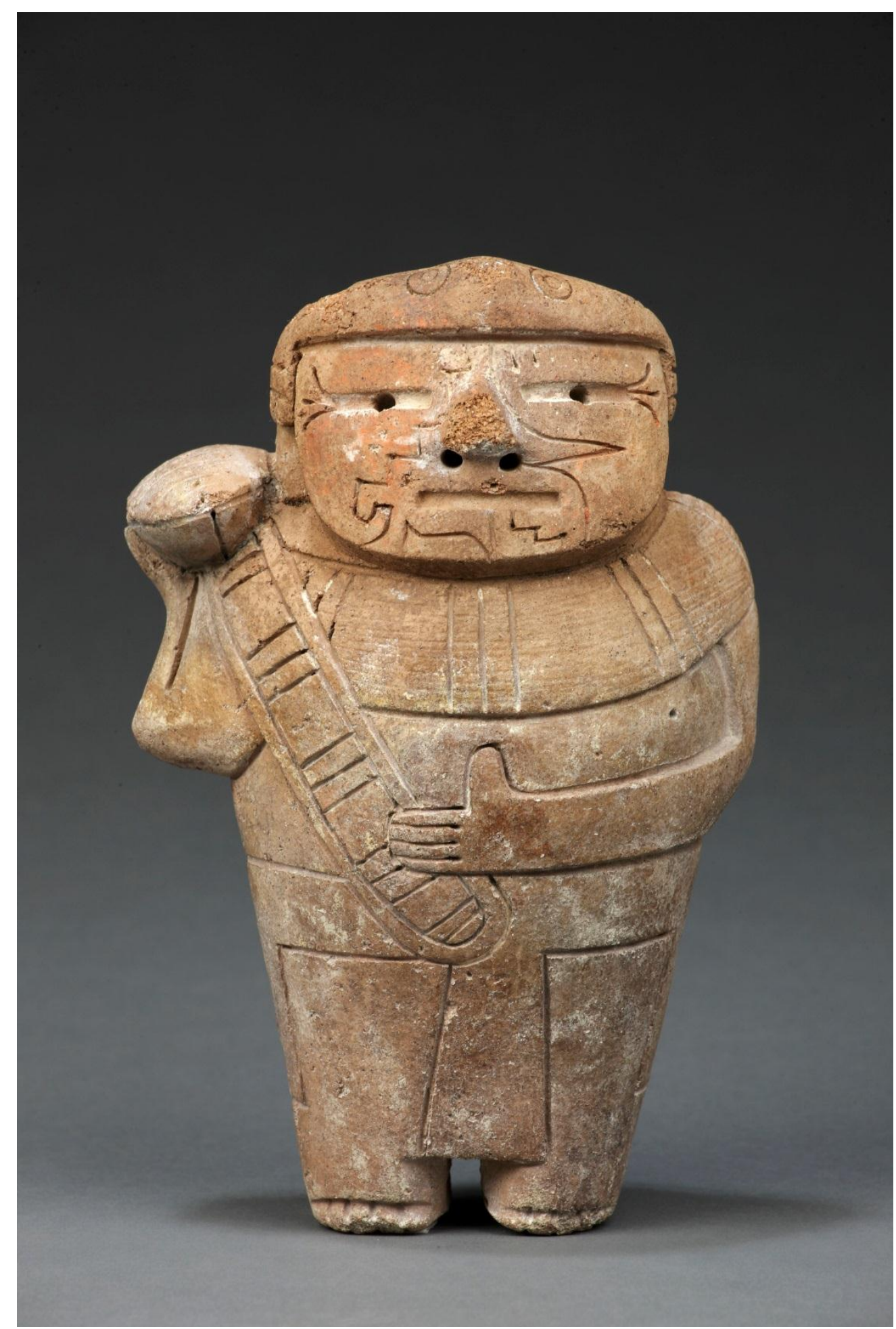

Figure 17. Ceramic figurine from the late Initial Period (1100-800 B.C.) found in the Jequetepeque valley, north of Gramalote. Although this artifact is later than the contexts here discussed, it shows how face decoration (see incised pattern filled with red paint) could have been used at Gramalote. Courtesy of the Museo de Arte de Lima, Peru. 